\title{
Bim controls IL-15 availability and limits engagement of multiple BH3-only proteins
}

\author{
S Kurtulus ${ }^{1}$, A Sholl ${ }^{1}$, J Toe ${ }^{2}$, P Tripathi ${ }^{1}$, J Raynor ${ }^{1}$, K-P Li ${ }^{1}$, M Pellegrini ${ }^{2}$ and DA Hildeman ${ }^{\star, 1}$
}

During the effector CD8 + T-cell response, transcriptional differentiation programs are engaged that promote effector T cells with varying memory potential. Although these differentiation programs have been used to explain which cells die as effectors and which cells survive and become memory cells, it is unclear if the lack of cell death enhances memory. Here, we investigated effector CD8 + T-cell fate in mice whose death program has been largely disabled because of the loss of Bim. Interestingly, the absence of Bim resulted in a significant enhancement of effector CD8 + T cells with more memory potential. Bim-driven control of memory T-cell development required T-cell-specific, but not dendritic cell-specific, expression of Bim. Both total and T-cell-specific loss of Bim promoted skewing toward memory precursors, by enhancing the survival of memory precursors, and limiting the availability of IL-15. Decreased IL-15 availability in Bim-deficient mice facilitated the elimination of cells with less memory potential via the additional pro-apoptotic molecules Noxa and Puma. Combined, these data show that Bim controls memory development by limiting the survival of pre-memory effector cells. Further, by preventing the consumption of IL-15, Bim limits the role of Noxa and Puma in causing the death of effector cells with less memory potential.

Cell Death and Differentiation (2015) 22, 174-184; doi:10.1038/cdd.2014.118; published online 15 August 2014

After an acute infection, most effector T cells die, whereas some remain and become a stable memory population. Over recent years, progress has been made in our understanding of this cell fate decision. For example, the effector population is heterogeneous, loosely identified by reciprocal expression of Killer cell lectin-like receptor G1 (KLRG1) and IL-7 R $\alpha$ (CD127). Adoptive transfer of $\mathrm{KLRG} 1{ }^{\mathrm{lo}} \mathrm{CD} 127^{\text {hi }}$ cells results in better survival and memory generation compared with their KLRG1 ${ }^{\text {hi }} \mathrm{CD} 127^{\mathrm{lo}}$ counterparts. ${ }^{1}$ These effector T-cell subsets are driven by distinct networks: a transcriptional program involving Blimp1, Id2 and t-bet is critical for the generation of $\mathrm{KLRG} 1{ }^{\mathrm{hi}} \mathrm{CD} 127^{\mathrm{lo}}$ effector cells, ${ }^{1-4}$ whereas an alternative transcriptional program involving Bcl-6, STAT3, eomoesodermin, Id3 and T-cell factor-1 are critical for the generation of $\mathrm{KLRG} 1{ }^{\mathrm{lo}} \mathrm{CD} 127^{\mathrm{hi}}$ pre-memory cells. ${ }^{5-10}$ Although these differentiation programs have been used to explain which cells die as effectors and which cells survive and become memory cells, the results are complicated by the fact that little work has been done examining effector CD8 ${ }^{+} \mathrm{T}$-cell responses in mice whose death programs have been disabled.

Although the extrinsic cell death pathway was initially thought to control contraction of T-cell responses, our and others data show a dominant role for the Bcl-2-regulated pathway. Germline deletion of the pro-apoptotic Bcl-2 family member, Bim, enhances $\mathrm{CD}^{+}{ }^{+}$and $\mathrm{CD}^{+}{ }^{+} \mathrm{T}$-cell responses to viral, bacterial and parasitic infection. ${ }^{11-14}$ One report suggested a minor role for another Bcl-2 homology domain 3 (BH3)-only Bcl-2 family member, Puma, although the role of Puma on effector T-cell subsets was not examined. ${ }^{15}$ Noxa has a marginal role in contraction of T-cell responses. ${ }^{16,17}$
Although Bim is the most dominant pro-apoptotic Bcl-2 family member driving contraction of T-cell responses, the study of $\mathrm{T}$-cell responses to acute infection in $\mathrm{Bim}^{-/}$mice is complicated by the ongoing autoimmune disease and altered negative selection in these mice. ${ }^{18}$ Further, other data suggest that dendritic cell (DC) expression of Bim can control the magnitude of T-cell responses. ${ }^{19}$ Thus, the cell-specific roles of Bim and the potential contributions of other proapoptotic Bcl-2 family members remain unclear.

Here, we report that T-cell-specific deletion of Bim recapitulated the effects of germline loss of Bim on the contraction of T-cell responses in vivo. Although Bim was critical to limit survival of $\mathrm{KLRG} 1^{\text {hi }} \mathrm{CD} 127^{\mathrm{lo}}$ cells at earlier phases after infection, the absence of Bim enriched for $\mathrm{KLRG} 1{ }^{\mathrm{lo}} \mathrm{CD} 127^{\mathrm{hi}}$ cells as the response progressed. This later loss of KLRG1 ${ }^{\text {hi }} \mathrm{C}$ $\mathrm{D} 127^{\mathrm{lo}}$ cells was due to the increased competition for IL-15 as a result of massive accumulation of effector $T$ cells in Bimdeficient environment. The combined loss of Bim and Puma or Bim and Noxa, significantly reduced contraction of CD8 ${ }^{+} \mathrm{T}$-cell responses compared with single-deficient mice. Together, our data show that effector T cells are kept in check first by Bim and then by limiting amounts of IL-15 (and likely other nutrients), which in turn trigger other $\mathrm{BH}$-only proteins.

\section{Results}

$\mathrm{KLRG1}^{\text {hi }}{ }^{\mathrm{CD}} 127^{\text {lo }}$ effector $\mathrm{CD8}{ }^{+} \mathrm{T}$ cells are transiently protected in the absence of Bim. We previously showed that $\mathrm{Bim}$ regulates the contraction of $\mathrm{T}$-cell responses during

${ }^{1}$ Department of Pediatrics, Division of Immunobiology at the Cincinnati Children's Hospital, University of Cincinnati College of Medicine, Cincinnati, OH 45229, USA and ${ }^{2}$ Infection and Immunity Division, The Walter and Eliza Hall Institute of Medical Research and Department of Medical Biology, University of Melbourne, Melbourne, Victoria 3052, Australia *Corresponding author: DA Hildeman, Department of Pediatrics, Division of Immunobiology MLC 7038, Children's Hospital Medical Center, 3333 Burnet Avenue, Cincinnati, OH 45229, USA. Tel: 513-636-3923; Fax: 513-636-5355; E-mail: David.Hildeman@cchmc.org

Abbreviations: LCMV, lymphocytic choriomeningitis virus; KLRG-1, Killer cell lectin-like receptor G1; BH3, Bcl-2 homology domain 3; WT, wild type; CRE, Cre recombinase; dLck, distal Lck promoter; $D C$, dendritic cell

Received 09.12.13; revised 27.5.13; accepted 10.7.14; Edited by S Fulda; published online 15 August 2014 
lymphocytic choriomeningitis virus (LCMV) infection. ${ }^{14}$ Recent work describing effector CD8 ${ }^{+}$T-cell heterogeneity prompted us to re-examine the effects of Bim within subsets of effector $\mathrm{CD}^{+}{ }^{+}$T cells with more $\left(\mathrm{KLRG} 1{ }^{\mathrm{lo}} \mathrm{CD} 127^{\mathrm{hi}}\right)$ or less $\left(\mathrm{KLRG} 1{ }^{\mathrm{hi}} \mathrm{C}\right.$ -

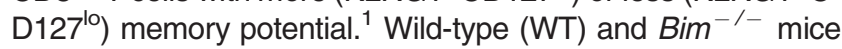
were infected with LCMV and the kinetics of GP33-specific effector $\mathrm{CD}^{+}$T-cell subsets tracked. The absence of Bim significantly increased the overall numbers of GP33-specific T cells, including both $\mathrm{KLRG} 1{ }^{\mathrm{hi}} \mathrm{CD} 127^{\mathrm{lo}}$ and $\mathrm{KLRG} 1^{\mathrm{lo}} \mathrm{CD} 127^{\mathrm{hi}}$ $\mathrm{CD}^{+}$effector subsets on days 10 and 15 after infection (Figure 1a). Importantly, the absence of Bim led to a nearly complete sparing of $\mathrm{KLRG} 1^{\mathrm{lo}} \mathrm{CD} 127^{\mathrm{hi}}$ cells through day 40 after infection (Figure 1a). Interestingly, after day 15, numbers of $\mathrm{KLRG} 1^{\text {hi }} \mathrm{CD} 127^{\mathrm{lo}}$ cells in $\mathrm{Bim}^{-/-}$mice slowly decreased and approached the levels observed in WT mice by day 40
(Figure 1a). The relatively minor population of KLRG $1^{\text {hi }} \mathrm{CD} 127^{\text {hi }}$ cells was also preserved in $\mathrm{Bim}^{-/-}$mice (Figures $1 \mathrm{a}-\mathrm{C}$ ). Thus, as the response progresses, the absence of Bim heavily favors $\mathrm{KLRG} 1^{\mathrm{lo}} \mathrm{CD} 127^{\text {hi }} \mathrm{CD} 8^{+} \mathrm{T}$ cells.

The environment of $\mathrm{Bim}^{-/-}$mice enriches for $\mathrm{KLRG}^{\mathrm{lo}} \mathrm{CD} 127^{\mathrm{hi}}$ effector $\mathrm{CD}^{+} \mathrm{T}$ cells. The differentiation of effector T-cell subsets is controlled by the cytokine milieu, pro-inflammatory cytokines direct the differentiation of $\mathrm{KLRG} 1{ }^{\text {hi }} \mathrm{CD} 127^{\mathrm{lo}}$ cells, whereas IL-10 and IL-21 guide the differentiation of $\mathrm{KLRG} 1^{\mathrm{lo}} \mathrm{CD} 127^{\mathrm{hi}}$ cells. ${ }^{1,7}$ No difference in the levels of serum IL-10 between WT and $\mathrm{Bim}^{-/-}$mice was observed at several time points (unpublished data). To determine whether the effects of Bim on subset differentiation were T-cell intrinsic, we adoptively transferred small

a
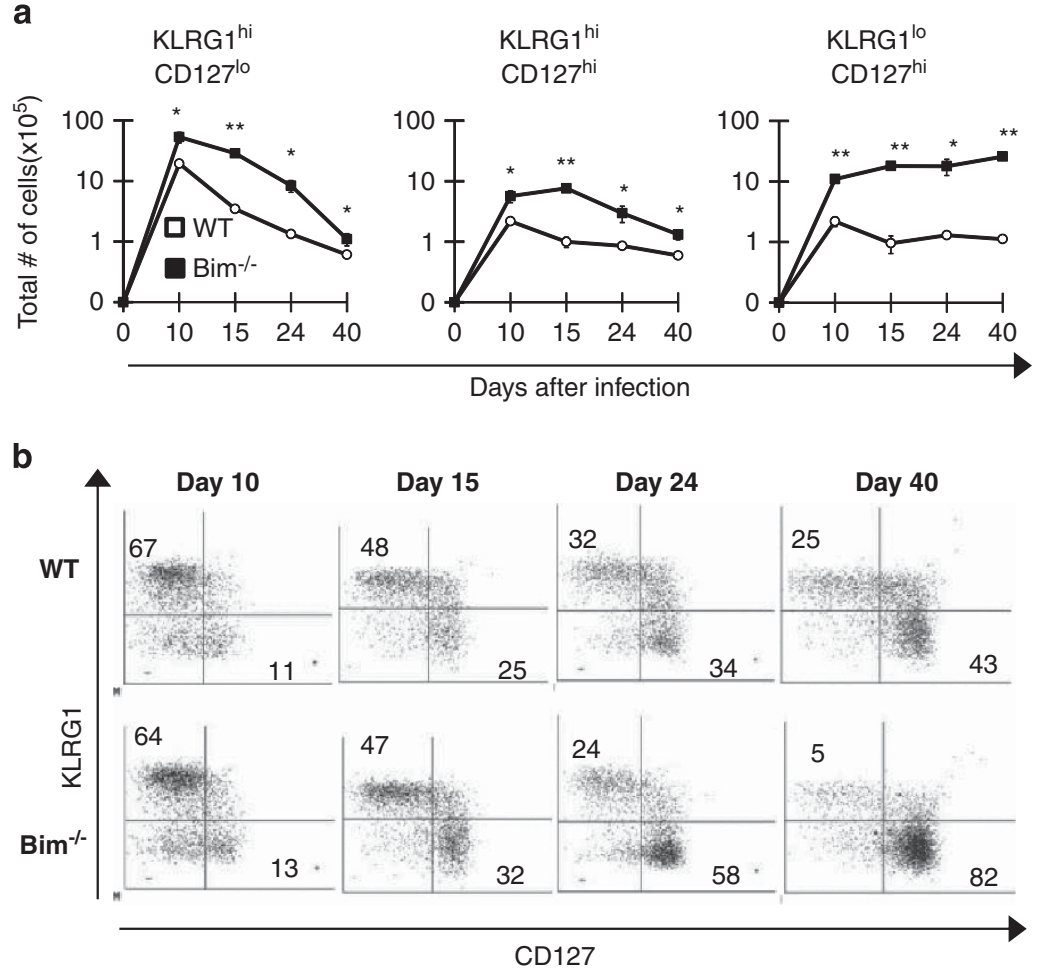

C
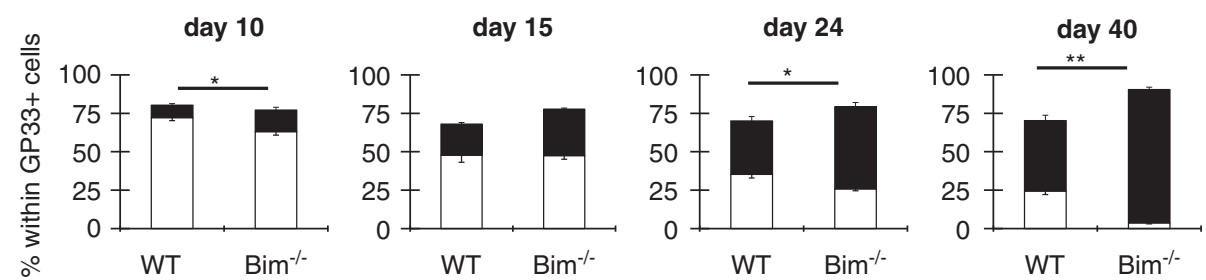

Figure 1 Bim is critical for the initial contraction of $\mathrm{KLRG} 1^{\mathrm{hi}} \mathrm{CD} 127^{10}$ effector $\mathrm{CD} 8^{+}$T cells. Groups of WT and Bim ${ }^{-/-}$mice $(n=4-6$ mice per genotype per time point) were infected intraperitoneally (i.p.) with $2 \times 10^{5}$ p.f.u./mouse LCMV and killed 10, 15, 24 or 40 days post LCMV infection. Splenocytes were stained with $D^{b}$-GP33 tetramers and antibodies against KLRG1, CD127, CD8 and CD44 and analyzed by flow cytometry. $D^{\mathrm{b}}$-GP33-specific CD8 ${ }^{+}$CD44 ${ }^{+}$cells were gated. (a) The graphs show the total numbers \pm S.E.M. of $\mathrm{KLRG} 1^{\mathrm{hi}} \mathrm{CD} 127^{\mathrm{lo}}, \mathrm{KLRG} 1^{\mathrm{hi}} \mathrm{CD} 127^{\mathrm{hi}}$ or $\mathrm{KLRG} 1{ }^{\mathrm{lo}} \mathrm{CD} 127^{\mathrm{hi}}$ subsets on indicated days after infection. (b) Representative dot plots for KLRG1 and CD127 are shown after gating on $\mathrm{CD} 8^{+} \mathrm{GP} 33^{+}$cells in each group on indicated days. (c) Graphs show percentages of $\mathrm{CD} 8^{+} \mathrm{GP} 33^{+} \mathrm{KLRG} 1^{\mathrm{hi}} \mathrm{CD} 127^{10}$ or $\mathrm{KLRG} 1^{\mathrm{l}} \mathrm{CD} 127^{\mathrm{hi}}$ subsets on indicated days after infection. Data are representative of two independent experiments. $P$ values for statistically significant differences were calculated by Student's $t$-test and ${ }^{*} P \leq 0.05$ and ${ }^{* *} P \leq 0.01$ 
numbers $\left(5 \times 10^{3}\right)$ of Thy $1.1^{+}$WT or $\mathrm{Bim}^{-/-}$P14 TCR transgenic $\mathrm{CD}^{+} \mathrm{T}$ cells, which are specific for an immunodominant LCMV-GP peptide 33-41, into Thy $1.2^{+}$ WT or Bim $^{-1-}$ hosts $^{20}$ and infected with LCMV a day later (Figure 2a). Subsequent analysis of blood revealed that host and donor p14 cells equally contributed to the response on day 10 , indicating that they did not suppress the endogenous response (Figure 2b). However, by day 20, the $\mathrm{Bim}^{-1-}$ GP33-specific effector $\mathrm{CD}^{+}{ }^{+} \mathrm{T}$ cells survived much better than WT effector cells regardless of whether the cells were of donor or recipient origin (Figure 2c). Curiously, when WT P14 cells were transferred into $\mathrm{Bim}^{-/-}$recipients, the remaining cells were largely $\mathrm{KLRG} 1{ }^{\mathrm{lo}} \mathrm{CD} 127^{\text {hi }}$ (Figures $2 \mathrm{~d}$ and e). Thus, although $\mathrm{Bim}^{-1-} \mathrm{T}$ cells dominated the response, the phenotype of emerging effector cells was influenced by host Bim expression.

Lack of Bim in DCs does not impact survival of effector CD8 $^{+}$T-cell subsets. Because Bim can control DC survival $^{19,21,22}$ and DCs are critical for effector to memory transition, ${ }^{19}$ we reasoned that the environmental effects of Bim might be driven by the effect of Bim on DCs. To test this, we generated conditional Bim-deficient mice by flanking exons 2, 3 and 4 of Bim with loxP sites $\left(\mathrm{Bim}^{f / f}\right)^{23}$ and then crossed them to mice expressing Cre recombinase (CRE) under the control of CD11c promoter $\left(\mathrm{CD} 11 \mathrm{cCRE}{ }^{+} \mathrm{Bim}^{f / \hbar}\right)$ to delete $\mathrm{Bim}$ in $\mathrm{CD}_{11 \mathrm{c}^{+}}$cells. Although the majority of

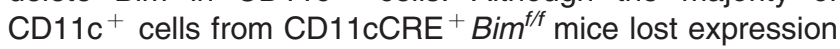
of Bim, Bim levels were also substantially decreased in most $T$ and $B$ cells from these mice (Figure $3 a$ ). This 'leakiness' precluded the direct use of these mice to interrogate the DC-specific role of Bim.

To circumvent this, we crossed $\mathrm{CD} 11 \mathrm{cCRE}{ }^{+} \mathrm{Bim}^{\mathrm{t} / \mathrm{f}}$ mice to Rag-deficient mice and generated $90: 10$ mixed bone marrow (BM) chimeras by transferring BM from $\mathrm{Rag}^{-/-} \mathrm{CD}^{11 \mathrm{CCRE}}{ }^{+}$ $\mathrm{Bim}^{\text {t/f }}\left(\mathrm{CD} 45.2^{+}, 90 \%\right)$ and WT (CD45.1 ${ }^{+}$CD45.2 $\left.{ }^{+}, 10 \%\right)$ into lethally irradiated $\mathrm{CD} 45.1$ recipient mice. In these chimeras, Bim-sufficient lymphocytes should develop, but the lack of Rag recombinase and the CD11C-CRE transgene will ensure that Bim deletion will be confined to nonlymphocyte populations, including DCs. Control chimeric mice were generated with 90:10 mix of BM from $\mathrm{Rag}^{-/} \mathrm{Bim}^{\mathrm{f} / \mathrm{f}}$ that lacked Cre expression and CD45.1/CD45.2 WT mice into CD45.1 recipients. To confirm reconstitution of mixed BM chimeras in congenic (CD45.1 $1^{+}$) recipient mice, we analyzed host $\left(\mathrm{CD} 45.1^{+}\right)$, donor WT (CD45.1 ${ }^{+}$CD45.2 $\left.{ }^{+}\right)$and donor $\mathrm{Rag}^{-/-} \mathrm{CD} 1 \mathrm{cCRE}{ }^{+} \mathrm{Bim}^{f / f}\left(\mathrm{CD} 45.2^{+}\right)$-derived T cells, B cells and $\mathrm{CD}_{11 \mathrm{C}^{+}}$cells. Cells derived from WT animals were largely $T$ and $B$ cells, whereas those derived from $\mathrm{Rag}^{-/-} \mathrm{CD}^{11 \mathrm{CCRE}}{ }^{+} \mathrm{Bim}^{\mathrm{f} / \mathrm{f}}$ mice contained no B or T cells as expected (Figure $3 \mathrm{~b}$ ). Indeed, $>97 \%$ of $\mathrm{TCR} \beta^{+}$cells were CD45. $1^{+}$, whereas $>94 \%$ of CD11c ${ }^{+}$cells were CD45.1 ${ }^{-}$. Importantly, the deletion of Bim was restricted to $\mathrm{CD} 11 \mathrm{C}^{+}$ cells derived from $\mathrm{Rag}^{-/-} \mathrm{CD}_{11 \mathrm{CCRE}}{ }^{+} \mathrm{Bim}^{\mathrm{f} / \mathrm{f}}$, but not from $\mathrm{Rag}^{-/-} \mathrm{Bim}^{\mathrm{f} / \mathrm{f}}$ donors (Figure 3c). Twelve weeks after reconstitution, groups of mixed BM chimeras were infected with LCMV and effector CD8 ${ }^{+}$T-cell responses assessed on days 10 and 24 after infection. Neither the expansion nor contraction of effector T-cell subsets was affected by deletion of Bim in non-lymphoid cells (Figure $3 d$ ). Thus, the lack of Bim a
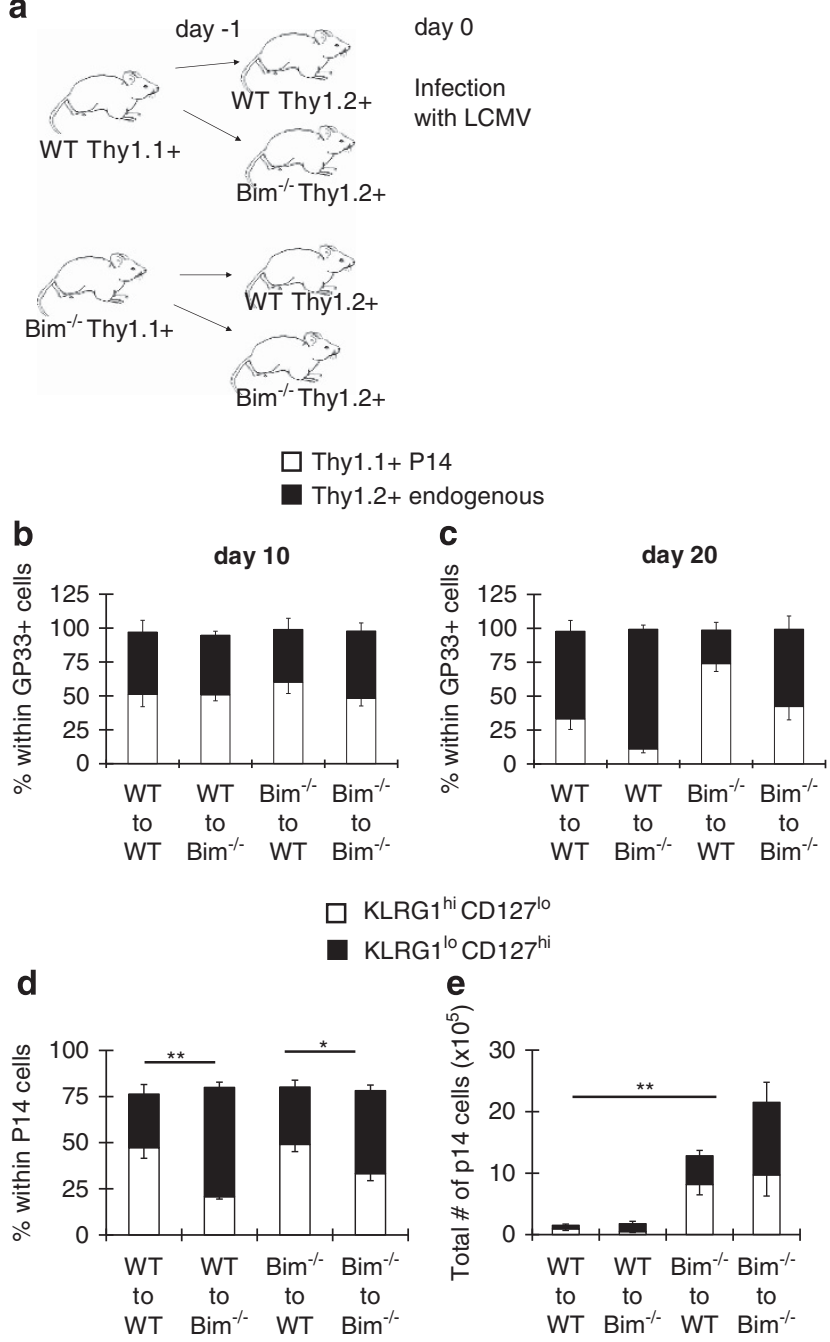

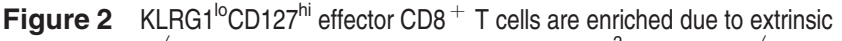
factors in $\mathrm{Bim}^{-1-}$ mice. (a) As depicted in the figure, $5 \times 10^{3} \mathrm{WT}_{\text {or }} \mathrm{Bim}^{-/-} \mathrm{P} 14$ Thy $1.1^{+} \mathrm{CD}^{+} \mathrm{T}$ cells were transferred into congenic WT or $\mathrm{Bim}^{-1-}$ mice ( $n=4-6$ recipient mice per genotype per timepoint) and infected with LCMV 1 day later. (b and c) Graphs show percentages of Thy $1.1^{+}$P14 or Thy $1.2^{+}$endogenous cells within $\mathrm{GP}_{3} 3^{+} \mathrm{CD} 8^{+} \mathrm{T}$ cells on day 10 (b) or day 20 (c) after infection. (d and e) Graphs show percentages (d) or total numbers (e) of KLRG1 $1^{\text {hi }} \mathrm{CD} 127^{\mathrm{lo}}$ or $\mathrm{KLRG} 1{ }^{\mathrm{lo}} \mathrm{CD} 127^{\mathrm{hi}}$ subsets within the total Thy $1.1^{+} \mathrm{P} 14$ cells analyzed on day 20 after infection. Data are representative of two independent experiments

in DCs does not impact expansion, survival or differentiation of effector $\mathrm{CD}^{+}{ }^{+} \mathrm{T}$ cells.

T-cell-specific loss of Bim increases survival of effector $\mathrm{CD8}^{+} \mathrm{T}$ cells with preferential enrichment for KLRG $1{ }^{\text {lo }} \mathrm{CD} 127^{\text {hi }}$ cells. Because the absence of Bim in $\mathrm{DCs}$ did not contribute to the skewing of $\mathrm{KLRG} 1^{\mathrm{lo}} \mathrm{CD} 127^{\mathrm{hi}}$ effector $\mathrm{CD}^{+} \mathrm{T}$ cells, we considered that the massive expansion of effector $T$ cells (of all epitopes) might limit cytokine availability. To test this, we crossed $\mathrm{Bim}^{f / f}$ mice to transgenic mice that express CRE under the promoter of distal Ick (dLckCRE), a promoter that is active late during thymic development. ${ }^{24}$ Importantly, deletion of Bim was nearly completely restricted to $\mathrm{T}$ cells, most $\mathrm{CD}^{+}$and $\mathrm{CD}^{+} \mathrm{T}$ cells had lost Bim expression, whereas Bim levels 
a

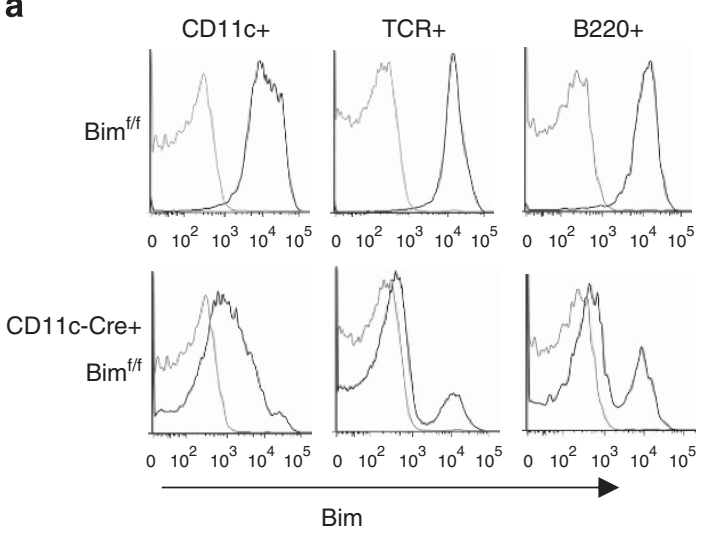

c

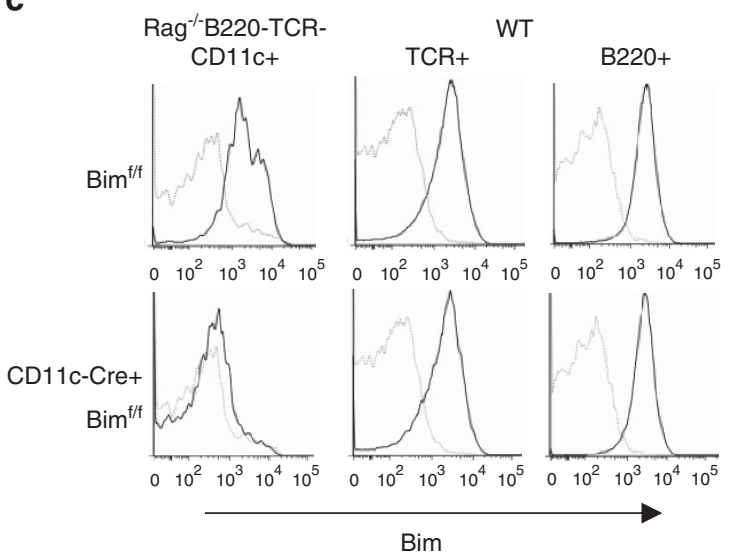

b
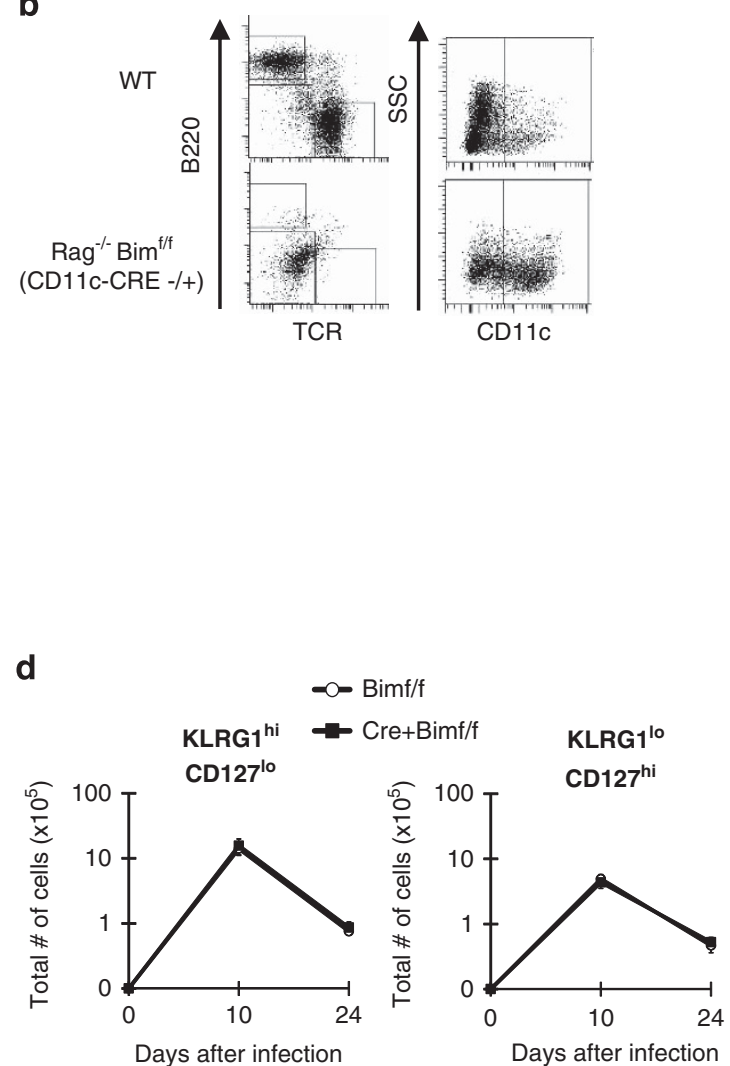

Figure 3 Lack of Bim in dendritic cells does not impact survival of effector CD8 ${ }^{+}$T-cell subsets. (a) Splenocytes from Bim ${ }^{f / f}$ and $\mathrm{CD}_{11 \mathrm{cCRE}}{ }^{+} \mathrm{Bim}^{f / f}$ mice were stained with antibodies against CD11c, CD11b and TCR and intracellularly against Bim. Histograms show staining for Bim (black) or isotype control (gray) in the indicated subsets from

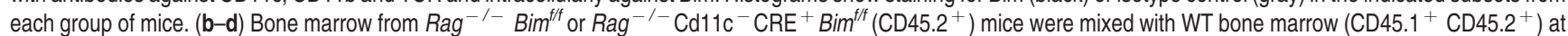
9:1 ratio and transferred into lethally irradiated WT (CD45.1 $\left.{ }^{+}\right)$congenic mice $(n=6$ recipient mice per genotype per time point). After $12-16$ weeks of engraftment, mice were

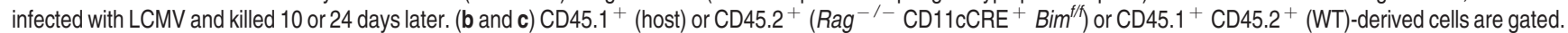
From these gates, $\mathrm{TCR}^{+},{\mathrm{B} 220^{+}}$or $\mathrm{TCR}^{-} \mathrm{B} 220^{-}$cells are gated. From B220 ${ }^{-} \mathrm{TCR}^{-}$cells, $\mathrm{CD}_{11 \mathrm{c}^{+}}$cells are gated. (c) Histograms show staining for Bim (black) or isotype control (gray) in the B220-TCR-CD11c +, TCR + or B220 + subsets indicated from each group of bone marrow chimeras. (d) Graphs show total numbers of CD8 ${ }^{+}$ $\mathrm{GP}_{3} 3^{+} \mathrm{KLRG} 1^{\mathrm{hi}} \mathrm{CD} 127^{\mathrm{lo}}$ or $\mathrm{KLRG} 1^{10} \mathrm{CD} 127^{\mathrm{hi}}$ subsets on indicated days after infection. Data are representative of two independent experiments

were normal in $\mathrm{TCR}^{-}$cells (Figure $4 \mathrm{a}$ ). We infected $\mathrm{Bim}^{\mathrm{f} / \mathrm{f}}$ and dLckCRE ${ }^{+}$Bim $^{f / f}$ mice with LCMV and analyzed T-cell responses. Notably, T-cell-specific deletion of Bim increased the total numbers of GP33-specific effector $\mathrm{CD}^{+}{ }^{+} \mathrm{T}$ cells (Figure 4b) and CD4 ${ }^{+} \mathrm{T}$ cells (unpublished data) on day 22 after infection. Similar to $\mathrm{Bim}^{-/-}$mice (Figures $1 \mathrm{a}-\mathrm{C}$ ), $\mathrm{KLRG} 1^{\mathrm{lo}} \mathrm{CD} 127^{\mathrm{hi}}$ cells were preferentially enriched in $\mathrm{dLckCRE}^{+} \mathrm{Bim}^{\mathrm{f} / \mathrm{f}}$ mice (Figure 4c). Thus, T-cell-specific deletion of Bim is sufficient to drive enrichment of $\mathrm{KLRG} 1{ }^{\mathrm{lo}} \mathrm{CD} 2127^{\mathrm{hi}}$ effector CD8 $+\mathrm{T}$ cells. We next reasoned that the enrichment of WT KLRG $1{ }^{\mathrm{lo}} \mathrm{CD} 127^{\text {hi }}$ effector cells in $\mathrm{Bim}^{-/-}$mice (Figures $2 \mathrm{c}$ and $\mathrm{d}$ ) may have been due to a massive overall T-cell expansion. Although the total numbers of $\mathrm{GP}^{+} 3^{+}$cells (including transferred and endogenous) were increased to a similar extent in both WT recipients of $\mathrm{Bim}^{-/-}$ p14 donors and $\mathrm{Bim}^{-/-}$recipients of WT p14 donors (Figure 4c), we note that the GP33-specific component of the LCMV response is only a fraction of the total response. As such, we examined the overall numbers of effector T cells $\left(C D 44^{\mathrm{hi}}\right)$ and found that they were increased substantially in $\mathrm{Bim}^{-/-}$recipients of either WT or $\mathrm{Bim}^{-/-}$donor cells
(Figure 4d). In contrast, overall numbers of CD44 ${ }^{\text {hi }}$ cells in WT recipients were not dramatically increased by the presence of either donor population (Figure 4d). Thus, the skewing of effector population occurs when a threshold level of $\mathrm{CD} 44^{\mathrm{hi}}$ cells is breached.

IL-15 enhances survival of Bim-deficient $\mathrm{KLRG} 1^{\text {hi }} \mathrm{C}$ $\mathrm{D127}^{\text {lo }}$ effector CD8 ${ }^{+} \mathrm{T}$ cells. As both global and T-cellspecific deletion of Bim led to a relative loss of $K L R G 1^{\text {hi }} \mathrm{C}$ D127 $7^{\mathrm{lo}}$ effector $\mathrm{CD}^{+}{ }^{+} \mathrm{T}$ cells later during infection, and IL-15 is required for survival of this subset, we reasoned that the massive effector response in $\mathrm{Bim}^{-/-}$mice may limit IL-15 availability. Quantification of $\mathrm{IL}-15$ is complicated as it is largely constitutively bound to IL-15R $\alpha^{25-27}$ Instead, we tested whether IL-15 would enhance survival of $\mathrm{KLRG} 1{ }^{\mathrm{hi}} \mathrm{C}$ D127 ${ }^{\mathrm{lo}}$ cells in $\mathrm{Bim}^{-/-}$mice. WT and $\mathrm{Bim}^{-/-}$mice were infected with LCMV and treated with either PBS or IL-15/IL$15 \mathrm{R} \alpha$ immune-complexes (IL-15-IC) on days 10, 12 and 14 and killed on day 15 after infection. Compared with PBStreated mice, IL-15 enhanced percentages and numbers of $\mathrm{KLRG} 1^{\text {hi }} \mathrm{CD} 127^{\mathrm{lo}}$ cells both in WT and $\mathrm{Bim}^{-/-}$mice 
(Figures $5 \mathrm{a}$ and b). Although IL-15 increased proliferation of both subsets, the effect was significantly greater in $\mathrm{KLRG} 1{ }^{\mathrm{lo}} \mathrm{CD} 127^{\text {hi }}$ cells relative to $\mathrm{KLRG} 1{ }^{\text {hi }} \mathrm{CD} 127^{\mathrm{lo}}$ cells, yet the latter cells were preferentially enriched (Figure $5 \mathrm{c}$ ). Further, KLRG $1^{\text {hi }} \mathrm{CD} 127^{\mathrm{lo}}$ cells proliferated even less in $\mathrm{Bim}^{-/-}$mice as $\mathrm{Bim}^{-/-}$cells proliferated less overall (Figure 5c). ${ }^{14}$ Thus, as their proliferation was lower, but yet they accumulated more, the data suggest that IL-15 modulated the survival of KLRG $1^{\text {hi }} \mathrm{CD} 127^{\text {lo }}$ cells and, further, that these effects were manifest in $\mathrm{Bim}^{-/-}$mice showed that they were independent of Bim.

Incomplete rescue of IL-15-deficient $\mathrm{KLRG}_{1}{ }^{\text {hi }} \mathrm{CD} 127^{\text {lo }}$ effector CD8 + T cells by the additional loss of Bim. To further test whether IL-15 antagonizes Bim, we transferred WT versus $\mathrm{Bim}^{-/-}$P14 cells into WT versus $\mathrm{IL-15^{-/- }}$ recipient mice. As expected, transfer of either WT or Bim ${ }^{-/-}$ P14 cells into $I L-15^{-/-}$recipients results in an enrichment of $\mathrm{KLRG} 1{ }^{\mathrm{l}} \mathrm{CD} 127^{\mathrm{hi}}$ cells compared with transfer into WT recipients (Figure 6a). We also generated $\mathrm{IL}-15 / \mathrm{Bim}$ double-deficient mice and infected them with LCMV along with WT, $I L-15^{-/-}$and $\mathrm{Bim}^{-/-}$controls. By day 24 after infection, the frequency of $\mathrm{KLRG} 1^{\text {hi }} \mathrm{CD} 127^{\mathrm{lo}}$ cells was dramatically decreased in $I L-15^{-/-}$mice and the additional loss of Bim only partly restored this subset (Figure 6b). Further, by day 40 after infection, the population had declined rapidly (Figure $6 \mathrm{c}$ ). Although $\mathrm{KLRG} 1^{\mathrm{lo}} \mathrm{CD} 127^{\text {hi }}$ cells were enriched in $I L-15^{-/-}$mice, their overall numbers were not changed compared with WT mice (Figure 6c). In addition, $\mathrm{KLRG} 1{ }^{\mathrm{lo}} \mathrm{CD} 127^{\mathrm{hi}}$ cells were increased substantially in $\mathrm{Bim}^{-/-}$mice whether or not IL-15 was present (Figure $6 \mathrm{c}$ ). Thus, the additional loss of Bim only partially and transiently restores $\mathrm{KLRG} 1^{\mathrm{hi}} \mathrm{CD} 127^{\mathrm{lo}}$ effector cells in $I L-15^{-/-}$mice. These data show that the scarcity of IL-15 may be responsible for the later Bim-independent decline of $\mathrm{KLRG} 1^{\text {hi }} \mathrm{CD} 127^{\mathrm{lo}}$ cells.

Given that Bim only partially restored $I L-15^{-/-} \mathrm{KLRG} 1^{\text {hi }} \mathrm{C}$ D127 ${ }^{\mathrm{lo}}$ effector cells and that exogenous IL-15 to promoted survival independent of Bim, we next determined whether additional pro-apoptotic molecules could restrict the survival of $\mathrm{KLRG} 1^{\text {hi }} \mathrm{CD} 127^{\mathrm{lo}}$ cells. Because $\mathrm{T}$ cells express multiple BH3-only molecules ${ }^{28}$ and each could potentially promote death, we examined responses in mice deficient in Bax and Bak, which are required for death driven by BH3-only proteins. ${ }^{29}$ We infected mice with a T-cell-specific loss of Bax in a $\mathrm{Bak}^{-/-}$background with LCMV and assessed the antiviral T-cell response in these mice. On day 10, the total numbers of GP33-specific CD8 ${ }^{+} \mathrm{T}$ cells were similar between $\mathrm{Bax}^{f / f} \mathrm{Bak}^{-/-}$and dLckCRE ${ }^{+} \mathrm{Bax}^{\mathrm{f} / f} \mathrm{Bak}^{-/-}$mice (Figure 6d). By day 24 after infection, the numbers of KLRG $1^{\text {hi }} \mathrm{CD} 127^{\text {lo }}$ effector cells were maintained in the absence of Bax and Bak (Figure 6d). Thus, it is likely that, in addition to Bim, other pro-apoptotic molecules, engaged by a lack of IL-15, contribute to the demise of $\mathrm{KLRG} 1^{\text {hi }} \mathrm{CD} 127^{\mathrm{lo}}$ cells.

Survival of $\mathrm{KLRG}^{\mathrm{hi}} \mathrm{CD} 127^{\mathrm{lo}}$ effector $\mathrm{CD} 8^{+} \mathrm{T}$ cells are limited by pro-apoptotic Bcl-2 family members. To identify additional pro-apoptotic $\mathrm{Bcl}-2$ family members that contribute to the loss of $\mathrm{KLRG} 1{ }^{\text {hi }} \mathrm{CD} 127^{\text {lo }}$ cells, we a

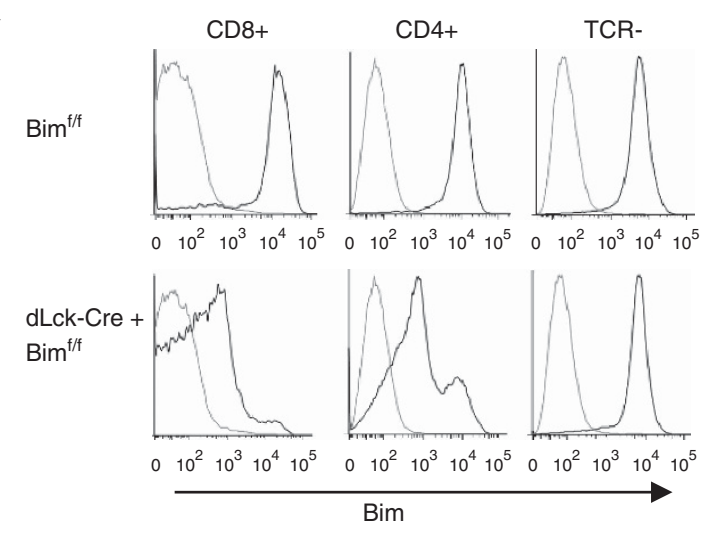

b

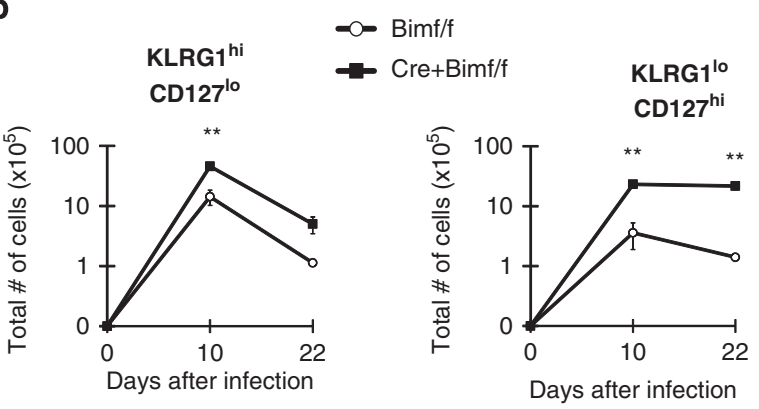

C
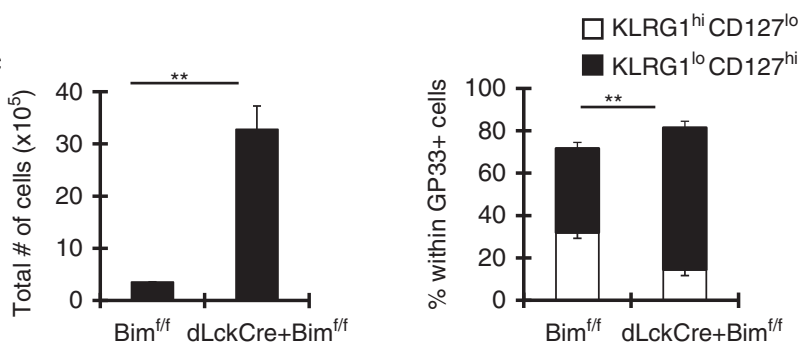

d
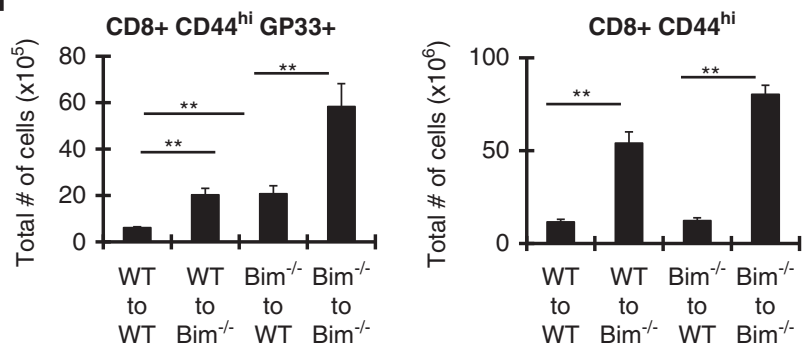

Figure 4 T-cell-specific loss of Bim increases survival of effector $\mathrm{CD} 8^{+} \mathrm{T}$ cells with preferential enrichment for $\mathrm{KLRG} 1^{10} \mathrm{CD} 127^{\text {hi }}$ cells. (a) Splenocytes from Bim ${ }^{\text {fft }}$ and $\mathrm{dLckCRE}^{+}$Bim $^{f / f}$ mice $(n=4)$ were stained with antibodies against CD8, CD4 and TCR and intracellularly against Bim. Histograms show staining for Bim (black) or isotype control (gray) in subsets indicated from each group of mice. (b and c) Bim ${ }^{\text {fft }}$ and $\mathrm{dLckCre}^{+}$Bim $^{f f}$ mice $(n=6-10)$ were infected with LCMV and killed 10 or 22 days later. (b) Graphs show total numbers of $\mathrm{CD} 8^{+} \mathrm{GP} 33^{+} \mathrm{KLRG}^{\text {hi }} \mathrm{CD} 127^{\mathrm{lo}}$ and $\mathrm{CD} 8^{+}$ $\mathrm{GP}_{3}{ }^{+} \mathrm{KLRG}^{\mathrm{lo}} \mathrm{CD} 127^{\mathrm{hi}}$ cells on indicated days after infection. (c) Graphs show total numbers of $\mathrm{CD} 8{ }^{+} \mathrm{GP} 33^{+}$cells or percentages of $\mathrm{CD} 8^{+} \mathrm{GP} 33^{+} \mathrm{KLRG} 1^{\text {hi }} \mathrm{CD} 127^{10}$ or $\mathrm{KLRG} 1{ }^{10} \mathrm{CD} 127^{\mathrm{hi}}$ subsets in indicated groups 22 days after infection. (d) $5 \times 10^{3} \mathrm{WT}$ or $\mathrm{Bim}^{-1-} \mathrm{P} 14$ Thy $1.1^{+} \mathrm{CD} 8{ }^{+}$T cells were transferred into congenic WT or Bim ${ }^{-1-}$ mice ( $n=4-6$ recipient mice per genotype per timepoint) and infected with LCMV 1 day later. Graphs show total numbers of $\mathrm{CD}^{+}{ }^{+} \mathrm{CD} 44^{\text {hi }}$ GP33-sp cells ( 14 and endogenous) versus overall $\mathrm{CD} 8{ }^{+} \mathrm{CD} 44^{\mathrm{hi}}$ cells in different recipient animals on day 20 after infection. Data are representative of three independent experiments. ${ }^{\star \star} P \leq 0.01$ 
a

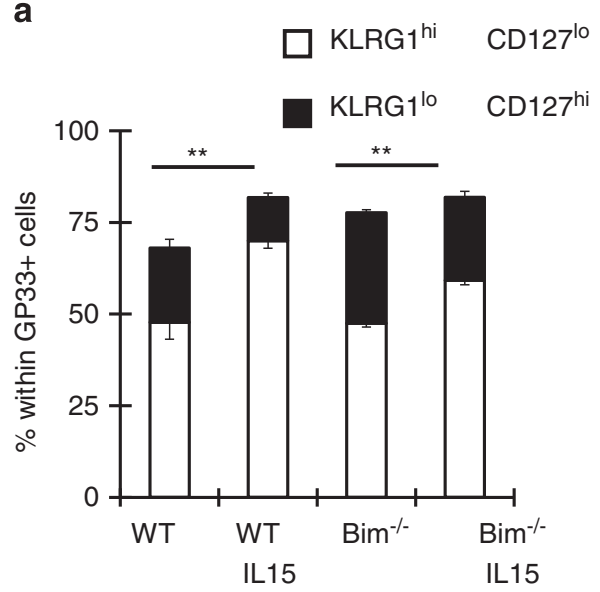

b

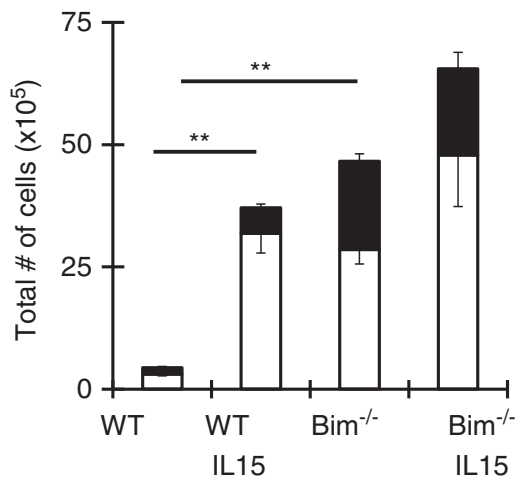

C

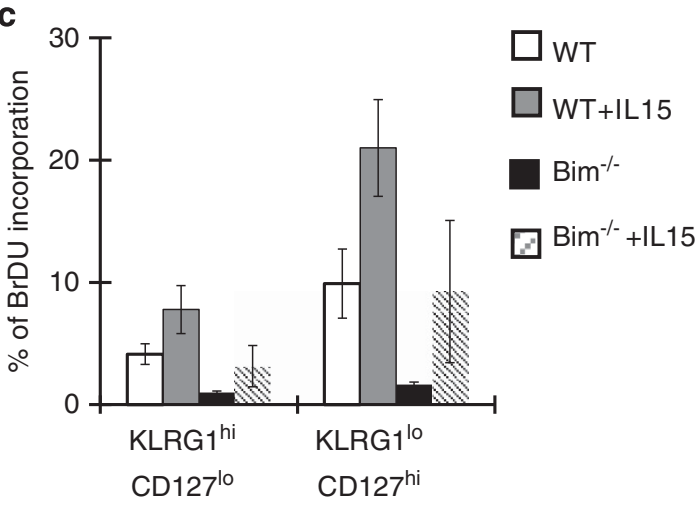

Figure 5 IL-15 enhances survival of Bim-deficient KLRG $1^{\text {hi }} \mathrm{CD} 127^{10}$ effector CD8 ${ }^{+}$T cells. (a and $\left.\mathbf{b}\right)$ Groups of WT or Bim ${ }^{-/-}$mice $(n=4$ per genotype) were infected with LCMV and treated either with PBS or IL-15/L-15R $\alpha$ immune-complexes (IL-15-IC) on days 10, 12 and 14 p.i. and killed on day 15. Splenocytes were stained with D'bp33 tetramers and antibodies against KLRG1, CD127 and CD8. Graphs show percentages (a) or numbers $(\mathbf{b})$ of CD8 ${ }^{+} \mathrm{GP} 33^{+} \mathrm{KLRG} 1^{\mathrm{hi}} \mathrm{CD} 127^{\mathrm{lo}}$ or KLRG $1{ }^{\mathrm{l}} \mathrm{CD} 127^{\mathrm{hi}}$ subsets on day 15 p.i. (c) Mice were also given BrDU the last 2 days before killing. Graph shows the percentages of $\mathrm{BrDU}^{+}$cells within each subset. Data are representative of two independent experiments. Similar results were obtained in dLck-CreBim ${ }^{\mathrm{t} / /}$ mice. ${ }^{* *} P \leq 0.01$

sort-purified KLRG $1^{\text {hi }} \mathrm{CD} 127^{\text {lo }}$ and $\mathrm{KLRG} 1{ }^{\mathrm{lo}} \mathrm{CD} 127^{\mathrm{hi}}$ cells on day 20 after infection and found that mRNA levels of Puma and Noxa were both increased (approximately two- to fourfold; Figure 7a). Likewise, at day 24 after infection, the levels of Puma and Noxa were significantly increased in $\mathrm{KLRG} 1{ }^{\text {hi }} \mathrm{CD} 127^{\mathrm{lo}}$ cells compared with $\mathrm{KLRG}{ }^{\mathrm{lo}} \mathrm{CD} 127^{\mathrm{hi}}$ cells (Figure $7 \mathrm{~b}$ ). We next determined the individual roles of Puma and Noxa as well as their combined roles with Bim in effector CD8 + T-cell subsets. The individual loss of Puma increased both the frequency and total numbers of KLRG $1{ }^{\text {hi }} \mathrm{CD} 127^{\mathrm{lo}}$ cells compared with WT mice on day 24 after infection (Figures 7c-f). Further, the combined loss of Puma and Bim restored the frequencies of $\mathrm{KLRG} 1^{\mathrm{hi}} \mathrm{CD} 127^{\mathrm{lo}}$ and $\mathrm{KLRG} 1{ }^{\mathrm{lo}} \mathrm{CD} 127^{\mathrm{hi}}$ cells to near WT levels (Figure 7c). Between days 10 and $24, \mathrm{KLRG} 1^{\mathrm{hi}} \mathrm{CD} 127^{\mathrm{lo}}$ cells contracted a little less in Puma- and Bim-deficient mice and substantially less in $\mathrm{dLckCreBim}^{\mathrm{f} / \mathrm{f}} \mathrm{Puma}^{-/-}$mice (Figures $7 \mathrm{~d}$ and e). Thus, Puma functions in a partially redundant manner with Bim to promote the demise of $\mathrm{KLRG} 1{ }^{\mathrm{hi}} \mathrm{CD} 127^{\mathrm{lo}}$ cells. The individual loss of Noxa had no effect on the frequency or total numbers of $\mathrm{KLRG} 1^{\mathrm{hi}} \mathrm{CD} 127^{\text {lo }}$ cells compared with WT mice (Figures $7 \mathrm{~g}-\mathrm{j}$ ). Similar to the loss of Puma and Bim, the combined loss of Noxa and Bim significantly reduced the contraction of $\mathrm{KLRG} 1^{\mathrm{hi}} \mathrm{CD} 127^{\mathrm{lo}}$ cells (Figures $7 \mathrm{~h}$ and $\mathrm{i}$ ). Thus, both Noxa and Puma collaborate with Bim to control effector CD8 + T-cell responses.

\section{Discussion}

Bim is crucial for the apoptotic contraction of T-cell responses to acute infection. ${ }^{11,14,30}$ This prior work has been complicated by potential non-T-cell autonomous role of Bim and the ongoing autoimmune disease in Bim-deficient mice due to altered thymic selection. Importantly, T-cell-specific loss of Bim recapitulates the $\mathrm{T}$-cell phenotype of mice with germline loss of Bim. Further, we showed that the lack of Bim in DCs did not affect the survival of effector $\mathrm{CD} 8^{+} \mathrm{T}$-cell subsets. These data might seem to contrast previous data showing that restricting expression of IL-15R $\alpha$ to $C D 11 \mathrm{C}^{+} \mathrm{DCs}$ resulted in a partial rescue of $\mathrm{KLRG} 1^{\mathrm{hi}} \mathrm{CD} 127^{\mathrm{lo}} \mathrm{CD} 8^{+} \mathrm{T}$ cells. ${ }^{31}$ However, only partial effects were observed in the prior study and we failed to observe enhancement of DCs in Bim-deficient mice during viral infection, suggesting that other cell types are important presenters of IL-15. Thus, Bim expression within DCs has little, if any, role on the magnitude or phenotype of the effector $\mathrm{CD}^{+}{ }^{+} \mathrm{T}$-cell response to acute viral infection. 

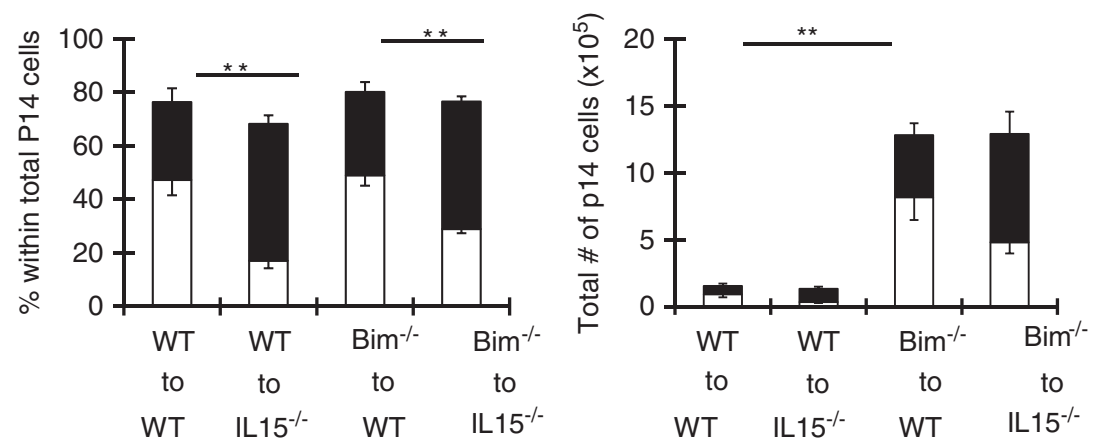

b
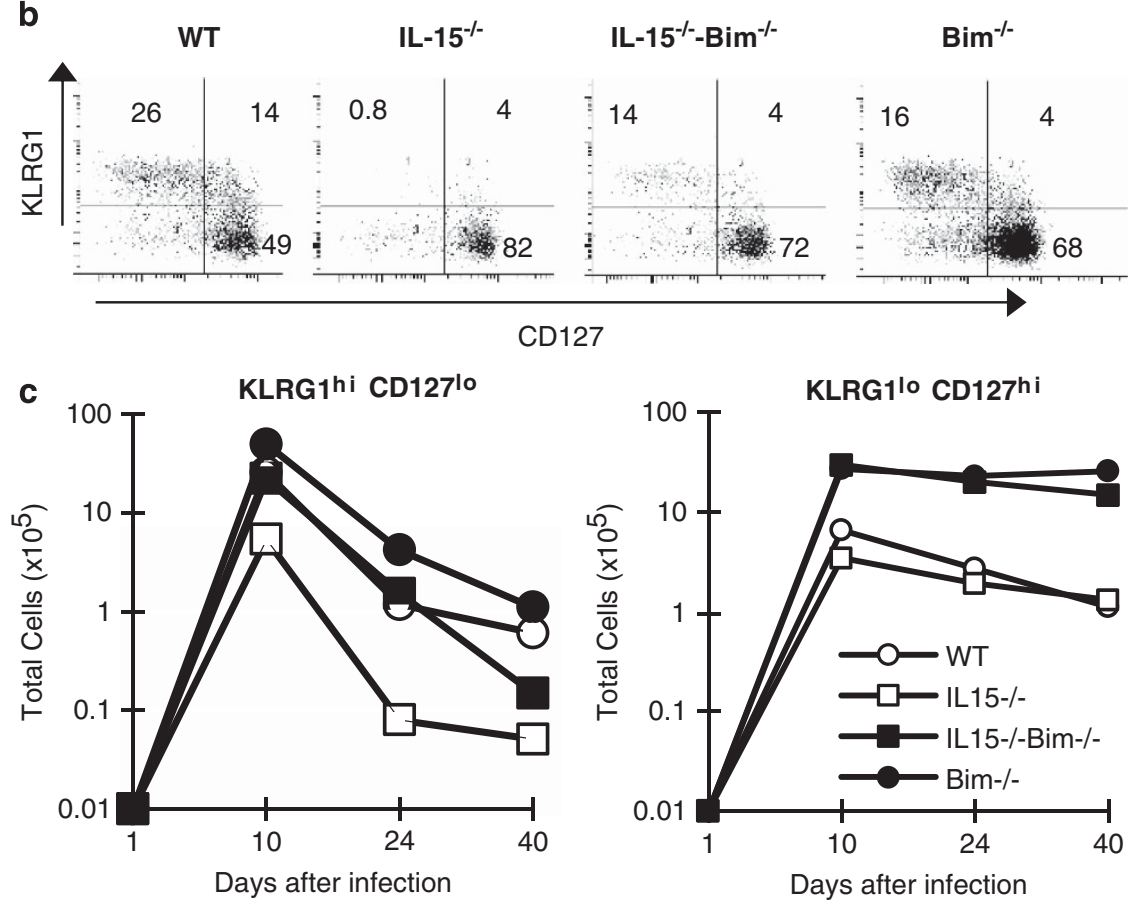

d

KLRG1hi CD127lo

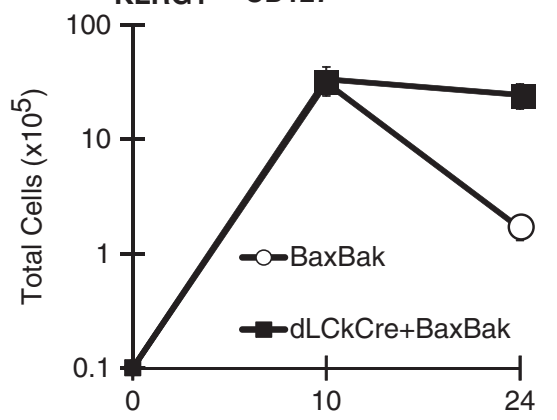

Days after infection

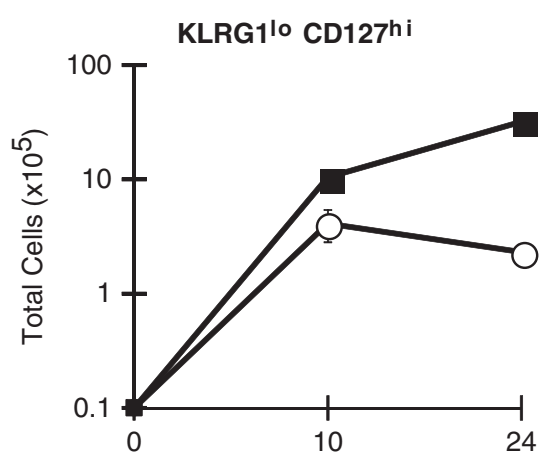

Days after infection

Figure 6 IL-15 regulates survival of KLRG $1^{\text {hi }} \mathrm{CD} 127^{10}$ effector cells by redundant pro-apoptotic Bcl-2 family members. (a) $5 \times 10^{3} \mathrm{WT}$ or Bim ${ }^{-/-} \mathrm{P} 14 \mathrm{Thy} 1.1^{+} \mathrm{CD} 8{ }^{+} \mathrm{T}$ cells were transferred into congenic WT or IL-15 ${ }^{-1-}(n=5-7)$ mice and infected with LCMV 1 day later. Graphs show percentages or numbers of KLRG ${ }^{\text {hi }} \mathrm{CD} 127^{10}$ or KLRG $1^{\text {lo }} \mathrm{CD} 127^{\mathrm{hi}}$

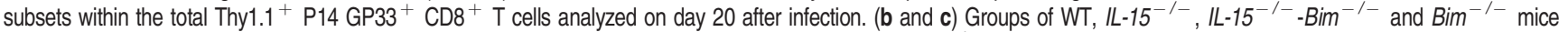
$(n=>10)$ were infected with LCMV and killed 10, 24 or 40 days later. Splenocytes were stained with H2D $D^{b}$-gp33 tetramers and antibodies against KLRG1, CD127 and CD8. (b) Representative dot plots and percentages of each subset are shown after gating on $\mathrm{CD} 8^{+} \mathrm{GP}_{3}{ }^{+}$cells in each group on day 24 p.i. (c) Graphs show total numbers of

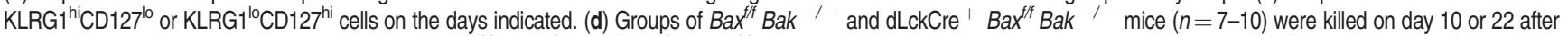
LCMV infection. Graphs show total numbers KLRG $1^{\text {hi }} \mathrm{CD} 127^{10}$ or $\mathrm{KLRG} 1^{10} \mathrm{CD} 127^{\text {hi }}$ cells on the days indicated. Results are representative of two independent experiments. ${ }^{* *} P \leq 0.01$ 
A major underlying mechanism that renders the enhanced death of $\mathrm{KLRG} 1^{\mathrm{hi}} \mathrm{CD} 127^{\mathrm{lo}}$ cells is their dependence upon IL-15 for survival. ${ }^{1,32-34} \mathrm{IL}-15$ is critical for maintaining expression of $\mathrm{Bcl}-2$, a major Bim antagonist in effector $\mathrm{CD}^{+}{ }^{+}$T cells. $^{33}$ The huge size of the anti-LCMV CD8 ${ }^{+} \mathrm{T}$-cell response, even in WT mice, likely limits the effector response by restricting IL-15 availability. ${ }^{34}$ Such IL-15 limitation likely enhances Puma expression in KLRG $1^{\text {hi }} \mathrm{CD} 127^{\text {lo }}$ cells relative to $\mathrm{KLRG} 1{ }^{\mathrm{lo}} \mathrm{CD} 127^{\mathrm{hi}}$ cells as the latter cells can utilize both IL-7 and IL-15 for survival. ${ }^{33}$ Further, we confirm and extend prior results, showing that Puma has a preferential effect on contraction of KLRG $1{ }^{\text {hi }} \mathrm{CD} 127^{\text {lo }}$ cells. ${ }^{15}$ Thus, in the absence of Bim, the enormous numbers of KLRG $1^{\text {hi }} \mathrm{CD} 127^{\text {lo }}$ cells act as a sink for IL-15 and likely other nutrients (glucose, amino acids) that prevent engagement of other $\mathrm{BH} 3$-only proteins. ${ }^{35}$

Although $\mathrm{Bcl}-2$ antagonizes Puma, $\mathrm{Bcl}-2$ has an extremely low affinity for Noxa. ${ }^{36,37}$ Instead, both $\mathrm{Mcl}-1$ and $\mathrm{A} 1$ have a higher affinity for Noxa. ${ }^{36,37}$ Noxa is activated by nutrient deprivation, potentially through maintenance of $\mathrm{Mcl}-1,{ }^{38}$ and can contribute to T-cell contraction in some model systems. ${ }^{16,39}$ Further, we recently showed that Mcl-1 was critical for effector T-cell survival and that the additional loss of Bim failed to restore Mcl-1-deficient effector T-cell responses. ${ }^{40}$ Thus, nutrients, by buffering Noxa with $\mathrm{Mcl}-1$, and cytokines, by buffering Bim and Puma with Bcl-2, control the magnitude and persistence of the effector T-cell pool. Alternatively, it is also possible that $\mathrm{Mcl}-1$ buffers the ability of Noxa, Puma and Bim to activate Bax and Bak and reduction of two out of the three is sufficient to promote substantial T-cell survival. Such redundancy is likely critical to avoid neoplasia and unwarranted immunopathologic T-cell responses.

The T-cell-specific loss of Bim promoted the accrual of effector T cells with pre-memory characteristics. Several nonmutually exclusive mechanism(s) may explain these data. First, KLRG $1^{\text {hi }} \mathrm{CD} 127^{\text {lo }}$ cells may convert to $\mathrm{KLRG} 1^{\mathrm{lo}} \mathrm{CD} 127^{\text {hi }}$ cells when death is uncoupled. Although suggested in a prior study, transfers of purified populations of effector subsets were not performed making it difficult to determine whether conversion had occurred. ${ }^{12}$ However, in other work, transferred WT KLRG $1^{\text {hi }}$ cells did not revert to $K L R G 1^{\text {lo }}$ cells; ${ }^{1,41,42}$ and here the numbers of $\mathrm{KLRG} 1{ }^{\mathrm{lo}} \mathrm{CD} 127^{\mathrm{hi}}$ cells in $\mathrm{Bim}^{-1-}$ mice did not increase in proportion to the loss of $\mathrm{KLRG} 1{ }^{\mathrm{hi}} \mathrm{C}$ $\mathrm{D} 127^{\mathrm{lo}}$ cells, arguing against conversion. More work is needed to determine if, in the absence of death, some $\mathrm{KLRG} 1{ }^{\text {hi }} \mathrm{CD} 127^{\mathrm{lo}}$ cells convert to $\mathrm{KLRG} 1^{\mathrm{lo}} \mathrm{CD} 127^{\text {hi }}$ cells. Second, the absence of Bim may protect $\mathrm{KLRG} 1^{\mathrm{lo}} \mathrm{CD} 127^{\mathrm{hi}}$ cells from death as many of these cells die in WT mice. ${ }^{1,14,33}$ $\mathrm{KLRG} 1{ }^{\mathrm{lo}} \mathrm{CD} 127^{\mathrm{hi}}$ cells are more protected from death because they express increased levels of $\mathrm{Bcl}-2$, as genetic loss or pharmacologic inhibition of Bcl-2 enhanced their Bimdriven death. ${ }^{33,43}$ Further, we have shown that a common $\gamma$ chain cytokine/STAT5/Bcl-2 network acts downstream of IL-7 and IL-15 to protect $\mathrm{KLRG} 1{ }^{\mathrm{lo}} \mathrm{CD} 127^{\text {hi }}$ effector T cells from Bim and likely Puma, favoring memory cell development. ${ }^{34}$ Third, as mentioned above, the massive expansion of effector and pre-memory subsets in $\mathrm{Bim}^{-/-}$mice severely restricts IL-15 availability for $\mathrm{KLRG} 1^{\mathrm{hi}} \mathrm{CD} 127^{\mathrm{lo}}$ cells. As both $\mathrm{KLRG} 1^{\mathrm{hi}} \mathrm{C}$ $\mathrm{D} 127^{\mathrm{lo}}$ and $\mathrm{KLRG} 1^{\mathrm{lo}} \mathrm{CD} 127^{\mathrm{hi}}$ cells express similar levels of CD122, it is unclear which subset contributes more to this population effect, although the sheer size of the
KLRG $1^{\text {hi }} \mathrm{CD} 127^{\text {lo }}$ compartment suggests a dominant role for this subset. Thus, although the forces driving contraction are operative in both effector populations, they are enhanced in KLRG $1{ }^{\text {hi }} \mathrm{CD} 127^{\text {lo }}$ cells and likely also involve Puma and Noxa.

Together with previous studies, our data indicate that survival and differentiation of effector $\mathrm{CD}^{+} \mathrm{T}$ cells are regulated by distinct mechanisms. For instance, IL-10/ IL-21/STAT3/SOCS3 signaling promotes skewing to $\mathrm{KLRG} 1{ }^{\mathrm{lo}} \mathrm{CD} 127^{\mathrm{hi}}$ cells, by shielding at them from proinflammatory cytokine/t-bet signaling. ${ }^{1,7}$ Importantly, the overall numbers of $\mathrm{CD}^{+}{ }^{+}$effector cells remained stable over time and neither t-bet nor STAT3 affected expression of Bcl$2,{ }^{1,7}$ suggesting that effector T-cell differentiation is separable from survival. In addition to differential STAT signaling, AKT/ FOXO signaling may be a critical node of integration. FOXO signaling promotes the formation of $\mathrm{KLRG} 1^{\mathrm{lo}}$ cells and their development into functional memory cells, but it also controls Bim expression. ${ }^{44,45}$ However, FOXO1 controls CD127 expression, making it difficult to precisely identify effector subsets. ${ }^{46}$ Nonetheless, an integration of death and differentiation signals may lie at the level of FOXO signaling. The ability to remove death from the equation (via the T-cellspecific loss of Bim or Bax and Bak) should be crucial for further dissection of these transcriptional networks.

These results may have potential therapeutic implications as Bcl-2 inhibitors can target autoreactive $\mathrm{T}$ cells and reduce autoimmunity. ${ }^{47,48}$ Conversely, although drugs that specifically target $\mathrm{BH} 3$-only molecules are not yet available, they could be vaccine adjuvants to enhance T-cell survival and memory development. Our data suggest that Bim is an excellent therapeutic target, in which overwhelming effector responses that might occur with Bim inhibition are self-limiting because of IL-15 availability, but would favor the emergence of long-lived memory T cells.

\section{Materials and Methods}

Mice and viral infection. C57BL/6 mice were either purchased from Jackson Labs (Bar Harbor, ME, USA) or Taconic Farms (Germantown, NY, USA). $\mathrm{Bim}^{-1-}$ mice were a gift from P Bouillet and A Strasser (Walter and Eliza Hall Institute, Melbourne, Victoria, Australia) and have been backcrossed to C57/BL6 mice for at least 14 generations. Bax ${ }^{\mathrm{t} / \mathrm{f}} \mathrm{Bak}^{-1-}$ mice were a gift of late Dr $\mathrm{S}$ Korsmeyer and were crossed to dLckCre (Jackson Labs). IL-15-deficient mice on a C57BL/6 background were purchased from Taconic Farms and were bred with $\mathrm{Bim}^{-1-}$ mice in our facility. Generation of Bim conditional mice $\left(\mathrm{Bim}^{t / /}\right)$ is as described. ${ }^{23}$ These mice were crossed to $\mathrm{dLckCRE}^{+}$or $\mathrm{CD} 11 \mathrm{cCRE}{ }^{+}$GFP mouse lines. P14 Thy1.1 ${ }^{+}$TCR transgenic mice were a gift of Dr M Jordan and were crossed to $\mathrm{Bim}^{-1-}$ mice. Rag1 ${ }^{-/-}$mice were purchased from Jackson Labs and crossed to CD11cCRE ${ }^{+}$GFP-Bim ${ }^{f / f}$ mice. CD45.1 $1^{+}$BoyJ mice were maintained in house and were crossed to $\mathrm{CD} 45.2^{+} \mathrm{C} 57 \mathrm{BL} / 6$ mice. C57BL/6$\mathrm{Bbc}^{\text {tm } 1 \mathrm{Ast}} / \mathrm{J}\left(\mathrm{Puma}^{-/-}\right.$) mice were purchased from Jackson Labs and were bred with $\mathrm{dLckCre}-\mathrm{Bim}^{\mathrm{f/f}}$ mice in our facility. C57BL-6-noxa ${ }^{-1-}$ mice were obtained from A Strasser (Walter and Eliza Hall Institute, Melbourne, Australia) and were described previously. ${ }^{49}$

Mice were infected i.p. with $2 \times 10^{5}$ p.f.u. of the lymphocytic choriomeningitis virus (LCMV). LCMV was grown in BHK-21 cells and viral titers from spleen and liver homogenates were determined by plaque assay on BHK-21 monolayers as described. For BrDU incorporation, mice were injected i.p. with three doses of $0.7 \mathrm{mg} / \mathrm{mouse}$ BrdU (BD Biosciences, San Jose, CA, USA) 2 days before killing ( 1 on day -2 and 2 on day -1 ). BrdU incorporation was assessed with BrdU Flow kit (BD Biosciences) according to the manufacturer's instructions. Animals were housed under specific pathogen-free conditions in the Division of Veterinary Services at Cincinnati Children's Hospital Research Foundation. Experimental procedures were reviewed and approved by the institutional animal care and use committee at the Cincinnati Children's Hospital Research Foundation. 

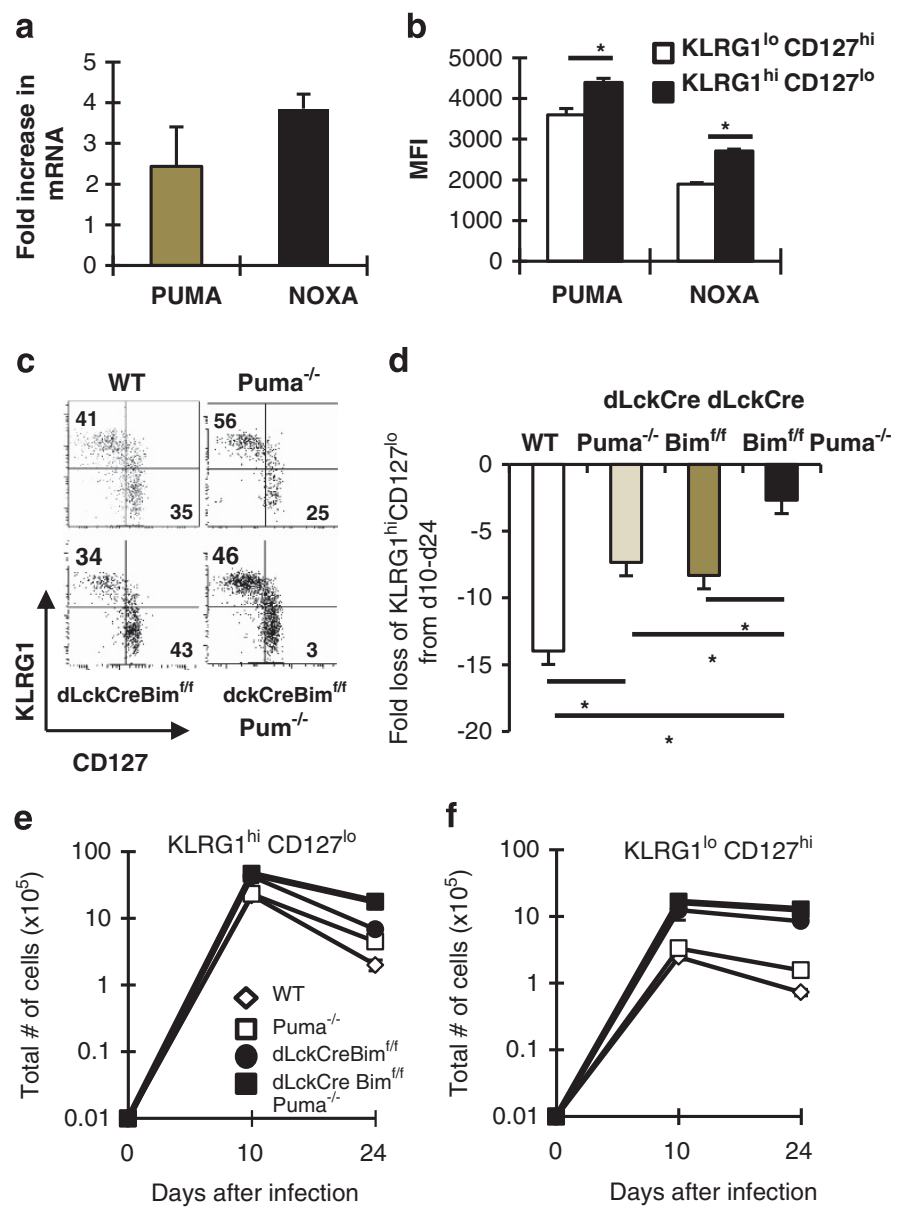

g

h
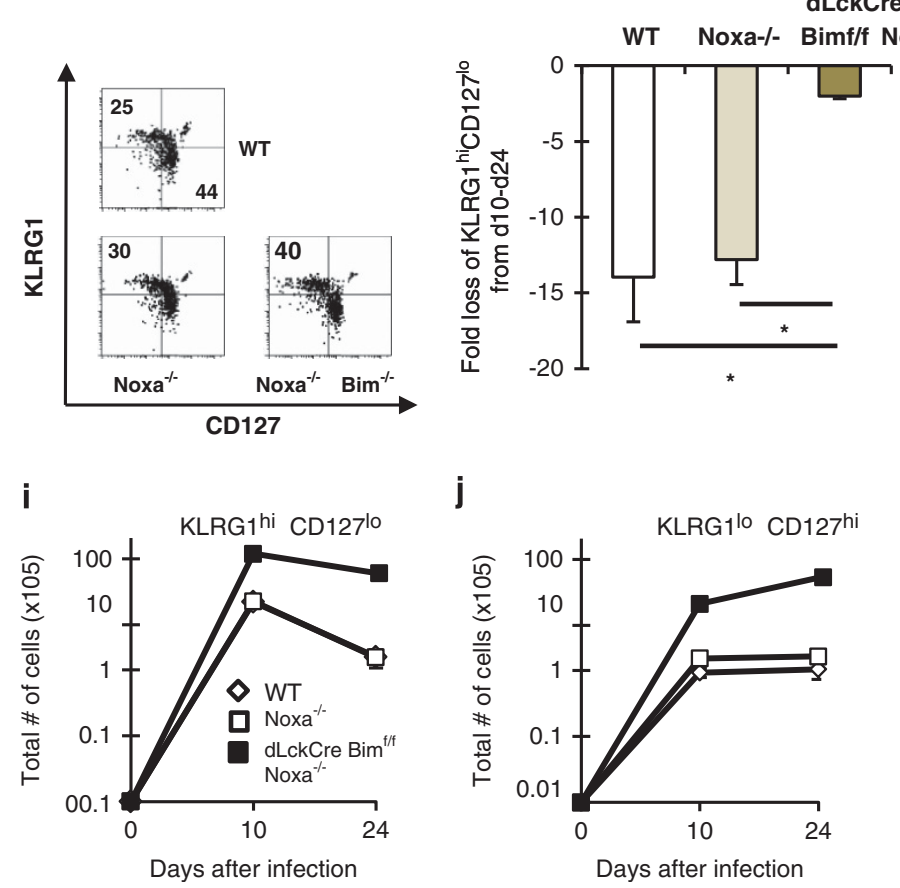
Figure 7 Bim, Noxa and Puma contribute to effector T-cell contraction. (a) Groups of C57BL/6 mice were infected with LCMV and on day 24 were killed and mRNA was isolated from sorted KLRG1 ${ }^{\text {hi }} \mathrm{CD} 127^{10}$ and KLRG $1^{10} \mathrm{CD} 127^{\text {hi }} \mathrm{CD} 8^{+} \mathrm{CD} 44^{\text {hi }} \mathrm{T}$ cells. Results show the fold increase in Puma and Noxa mRNA in KLRG1 ${ }^{\text {hi }} \mathrm{CD} 127^{\mathrm{lo}}$ relative to $\mathrm{KLRG} 1{ }^{10} \mathrm{CD} 127^{\mathrm{hi}} \mathrm{T}$ cells as assessed by real-time RT-PCR. Cycle counts for Puma and Noxa were normalized to actin before assessment of fold increase. (b) Groups of C57BL/6 mice were infected with LCMV and on day 24 were killed and spleen cells were stained with MHC tetramers and antibodies against CD8, CD44, KLRG1, intracellularly with antibodies against Noxa and Puma. Results show the mean fluorescence intensity of the Noxa or Puma signal in pre-memory KLRG $1^{10} \mathrm{CD} 127^{\text {hi }}$ (white bars)

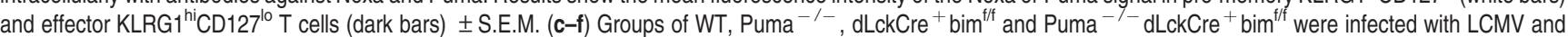

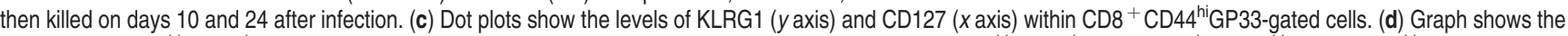
fold loss of KLRG $1^{\text {hi }} \mathrm{CD} 127^{10}$ cells between days 10 and 24. (e and f) Graphs show the total numbers of KLRG $11^{\text {hi }} \mathrm{CD} 127^{10}$ and KLRG $1{ }^{\text {lo }} \mathrm{CD} 127^{\mathrm{hi}} \mathrm{CD} 8^{+} \mathrm{CD} 44^{\mathrm{hi}} \mathrm{GP} 33-\mathrm{Specific} T$

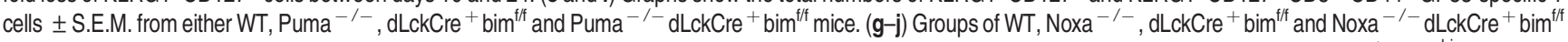
were infected with LCMV and then killed on days 10 and 24 after infection. (g) Dot plots show the levels of KLRG1 ( $y$ axis) and CD127 ( $x$ axis) within CD8 ${ }^{+}$CD44 ${ }^{\text {hi }}$ GP33-gated cells and (h) graph shows the fold loss of KLRG1 ${ }^{\text {hi }} \mathrm{CD} 127^{\text {lo }}$ cells between days 10 and 24 . (i and j) Graphs show the total numbers of $\mathrm{KLRG} 1^{\mathrm{hi}} \mathrm{CD} 127^{10}$ and $\mathrm{KLRG} 1{ }^{\text {lo }} \mathrm{CD} 127^{\mathrm{hi}}$ $\mathrm{CD}^{+}$CD $44^{\text {hi }}$ GP33-specific T cells \pm S.E.M. from either WT, Noxa ${ }^{-/-}, \mathrm{dLckCre}^{+} \mathrm{bim}^{\mathrm{ft} / \mathrm{f}}$ and Noxa ${ }^{-/-} \mathrm{dLckCre}^{+}$bim $^{\mathrm{ff/}}$ mice on days 10 and 24 after infection. Results are pooled from two to three independent experiments. *Significant difference as assessed by Student's $t$-test and $P \leq 0.01$

Adoptive transfer experiments. $\mathrm{CD}^{+}{ }^{+} \mathrm{T}$ cells were isolated by MACS $\mathrm{CD}^{+}$isolation kit (Miltenyi Biotec, San Diego, CA, USA) from spleens of WT or $\mathrm{Bim}^{-1-}$ Thy $1.1^{+} \mathrm{P} 14$ transgenic mice according to the manufacturer's instructions. $5 \times 10^{3}$ cells were transferred into C57BL/6, Bim ${ }^{-1-}$ or IL-15 mice intravenously (i.v.) and the mice were infected with $2 \times 10^{5}$ p.f.u. LCMV i.p. a day later.

Reconstitution with mixed BM chimera. BM from four limbs of $\mathrm{Rag}^{-/-}$ $\mathrm{Bim}^{t / f}, \mathrm{Rag}^{-1-} \mathrm{CD}_{11 \mathrm{CCRE}}{ }^{+} \mathrm{Bim}^{t / 4}$ or $\mathrm{CD} 45.2^{+} \mathrm{CD} 45.1^{+}$mice was isolated by crushing the bones and passing cells through a $70-\mu \mathrm{m}$ mesh cup (BD Falcon, San Jose, CA, USA) to generate single-cell suspensions. Suspensions were washed several times with PBS. In the meantime, CD45.1 ${ }^{+}$BoyJ mice were lethally irradiated. BM from CD45.2 ${ }^{+} \mathrm{CD} 45.1^{+}$mice was mixed at a 1:9 ratio with $\mathrm{Rag}^{-1-}$

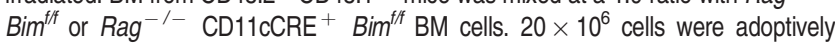
transferred i.v. to lethally irradiated CD45.1 ${ }^{+}$BoyJ mice. These mice then were fed with antibiotic-treated food for 2-3 weeks. Mice were i.p. infected with LCMV after 3-4 months.

MHC tetramer staining and flow cytometry. Spleens from individual mice were harvested and crushed through a $70-\mu \mathrm{m}$ mesh cup (BD Falcon) to generate single-cell suspensions. $2 \times 10^{6}$ cells were stained with different combinations of the following cell surface antibodies: anti-CD8, CD4, CD44, KLRG1, CD127, CD45.1, CD45.2, Thy1.1, Thy1.2, CD11c, TCR, CD11b and B220 (from Bio-Legend or EBioscience, San Diego, CA, USA) and intracellularly with anti-Bim (Cell Signaling Technology, Beverly, MA, USA) as described. D ${ }^{b}$ gp33 monomers were produced in house and were coupled to either APC or to PE as previously described. ${ }^{14}$ Minimum of $5 \times 10^{5}$ events were acquired on a BD LSR II flow cytometer and analyzed by either FACS DIVA or Flowjo, Treestar software.

IL-15 administration in vivo. For IL-15 delivery experiments, IL-15/L$15 R \alpha$ (R\&D Systems, Minneapolis, MN, USA) were mixed in vitro, and the equivalent of $750 \mathrm{ng}$ IL-15 was injected i.p. on days 8, 10, 12 and 14 post infection. IL-15/IL-15R $\alpha$ complexes were given instead of IL-15 because of their longer in vivo half-life.

Real-time RT-PCR. Effector (CD8 $\left.+\mathrm{CD} 44^{\text {hi }} \mathrm{KLRG} 1^{\text {hi }} \mathrm{CD} 127^{7^{\circ}}\right)$ and pre-memory (CD8 $\left.+\mathrm{CD} 44^{\text {hi }} \mathrm{KLRG} 1^{10} \mathrm{CD} 127^{\mathrm{hi}}\right) \mathrm{T}$ cells were sorted from the spleens of d24 LCMV-infected mice, whereas naive (CD8 + CD44 $\left.{ }^{10} \mathrm{KRLG} 1{ }^{10} \mathrm{CD} 127^{\mathrm{hi}}\right) \mathrm{T}$ cells were sorted from uninfected mice on a FACSAria cell sorter. RNA was isolated from cells using Qiagen's RNeasy mini isolation kit (Qiagen, Valencia, CA, USA) and converted into cDNA using Superscript II Reverse transcriptase (Invitrogen, Grand Island, NY, USA). Primers used were: Puma F: 5'-ACCTCAACGCGCAGTACGA-3'; Puma R: 5'-GGAGGAGTCCCATGAAGAGATTG-3'; Noxa F: 5'-GGAGTGCACCG GACATAACT-3', Noxa R: 5'-TTGAGCACACTCGTCCTTCA-3, beta-actin F: $5^{\prime}$-GACGGCCAAGTCATCACTATTG-3', $\beta$-actin R: $5^{\prime}$-GAAGGAAGGCTGGAAAA GAGC-3' Real-time PCR was performed in IQ Cycler PCR Machine (Bio-Rad, Hercules, CA, USA).

\section{Conflict of Interest}

The authors declare no conflict of interest.
Acknowledgements. We thank members of the Hildeman lab for helpful suggestions.. S Kurtulus was supported by a Dean's Distinguished Graduate Fellowship Award from the University of Cincinnati. This work was supported by Public Health Service Grants Al053357 and DK081175 (DAH), and by NIH grants P30 DK078392, DK090971 supporting the Research Flow Cytometry Core in the Digestive Disease Core Center and the Center of Excellence in Molecular Hematology.

\section{Author Contributions}

SK, MP and DH conceived and designed the experiments. SK, AS, JR, JT, PT and K-PL performed the experiments. SK, JT, PT, K-PL, MP and DH analyzed the data. SK and DH wrote the paper.

1. Joshi NS, Cui W, Chandele A, Lee HK, Urso DR, Hagman J et al. Inflammation directs memory precursor and short-lived effector CD8 $(+)$ T cell fates via the graded expression of T-bet transcription factor. Immunity 2007; 27: 281-295.

2. Cannarile MA, Lind NA, Rivera R, Sheridan AD, Camfield KA, Wu BB et al. Transcriptional regulator Id2 mediates CD8 + T cell immunity. Nat Immunol 2006; 7: 1317-1325.

3. Kallies A, Xin A, Belz GT, Nutt SL. Blimp-1 transcription factor is required for the differentiation of effector CD8 $(+)$ T cells and memory responses. Immunity 2009; 31: 283-295.

4. Rutishauser RL, Martins GA, Kalachikov S, Chandele A, Parish IA, Meffre E et al. Transcriptional repressor Blimp-1 promotes $\mathrm{CD} 8(+) \mathrm{T}$ cell terminal differentiation and represses the acquisition of central memory $\mathrm{T}$ cell properties. Immunity 2009; 31: 296-308

5. Intlekofer AM, Takemoto N, Wherry EJ, Longworth SA, Northrup JT, Palanivel VR et al. Effector and memory CD8 + T cell fate coupled by T-bet and eomesodermin. Nat Immunol 2005; 6: 1236-1244.

6. Ichii H, Sakamoto A, Hatano M, Okada S, Toyama H, Taki S et al. Role for Bcl-6 in the generation and maintenance of memory CD8 + T cells. Nat Immunol 2002; 3: 558-563

7. Cui W, Liu Y, Weinstein JS, Craft J, Kaech SM. An interleukin-21-interleukin-10-STAT3 pathway is critical for functional maturation of memory CD8 + T cells. Immunity 2011; 35: 792-805

8. Monticelli LA, Sonnenberg GF, Abt MC, Alenghat T, Ziegler CG, Doering TA et al. Innate lymphoid cells promote lung-tissue homeostasis after infection with influenza virus. Nat Immunol 2011; 12: 1045-1054.

9. Ji Y, Pos Z, Rao M, Klebanoff CA, Yu Z, Sukumar M et al. Repression of the DNA-binding inhibitor Id3 by Blimp-1 limits the formation of memory CD8 + T cells. Nat Immunol 2011; 12: $1230-1237$.

10. Zhou X, Yu S, Zhao DM, Harty JT, Badovinac VP, Xue HH. Differentiation and persistence of memory CD8 $(+)$ T cells depend on T cell factor 1. Immunity 2010; 33: 229-240.

11. Pellegrini M, Belz G, Bouillet $P$, Strasser A. Shutdown of an acute T cell immune response to viral infection is mediated by the proapoptotic Bcl-2 homology 3-only protein Bim. Proc Natl Acad Sci USA 2003; 100: 14175-14180.

12. Prlic M, Bevan MJ. Exploring regulatory mechanisms of $\mathrm{CD} 8+\mathrm{T}$ cell contraction. Proc Natl Acad Sci USA 2008; 105: 16689-16694.

13. Reckling S, Divanovic S, Karp CL, Wojciechowski S, Belkaid Y, Hildeman D. Proapoptotic Bcl-2 family member Bim promotes persistent infection and limits protective immunity. Infect Immun 2008; 76: 1179-1185.

14. Wojciechowski S, Jordan MB, Zhu Y, White J, Zajac AJ, Hildeman DA. Bim mediates apoptosis of CD127(lo) effector T cells and limits T cell memory. Eur J Immunol 2006; 36: 1694-1706. 
15. Fischer SF, Belz GT, Strasser A. BH3-only protein Puma contributes to death of antigen-specific $T$ cells during shutdown of an immune response to acute viral infection. Proc Natl Acad Sci USA 2008; 105: 3035-3040.

16. Wensveen FM, Klarenbeek PL, van Gisbergen KP, Pascutti MF, Derks IA, van Schaik BD et al. Pro-apoptotic protein Noxa regulates memory $T$ cell population size and protects against lethal immunopathology. J Immunol 2013; 190: 1180-1191.

17. Wensveen FM, van Gisbergen KP, Derks IA, Gerlach C, Schumacher TN, van Lier RA et al. Apoptosis threshold set by Noxa and Mcl-1 after T cell activation regulates competitive selection of high-affinity clones. Immunity 2010; 32: 754-765.

18. Bouillet P, Metcalf D, Huang DC, Tarlinton DM, Kay TW, Kontgen F et al. Proapoptotic Bcl-2 relative Bim required for certain apoptotic responses, leukocyte homeostasis, and to preclude autoimmunity. Science 1999; 286: 1735-1738.

19. Chen M, Huang L, Wang J. Deficiency of Bim in dendritic cells contributes to overactivation of lymphocytes and autoimmunity. Blood 2007; 109: 4360-4367.

20. Kearney ER, Pape KA, Loh DY, Jenkins MK. Visualization of peptide-specific $T$ cell immunity and peripheral tolerance induction in vivo. Immunity 1994; 1: 327-339.

21. Wan CK, Oh J, Li P, West EE, Wong EA, Andraski AB et al. The cytokines IL-21 and GM-CSF have opposing regulatory roles in the apoptosis of conventional dendritic cells. Immunity 2013; 38: 514-527.

22. Hou WS, Van Parijs L. A Bcl-2-dependent molecular timer regulates the lifespan and immunogenicity of dendritic cells. Nat Immunol 2004; 5: 583-589.

23. Raynor J, Sholl A, Plas DR, Bouillet P, Chougnet CA, Hildeman DA. IL-15 Fosters Age-Driven Regulatory T Cell Accrual in the Face of Declining IL-2 Levels. Front Immunol 2013; 4: 161.

24. Zhang DJ, Wang Q, Wei J, Baimukanova G, Buchholz F, Stewart AF et al. Selective expression of the Cre recombinase in late-stage thymocytes using the distal promoter of the Lck gene. J Immunol 2005; 174: 6725-6731.

25. Dubois S, Mariner J, Waldmann TA, Tagaya Y. IL-15Ralpha recycles and presents IL-15 In trans to neighboring cells. Immunity 2002; 17: 537-547.

26. Lodolce JP, Burkett PR, Boone DL, Chien M, Ma A. T cell-independent interleukin 15Ralpha signals are required for bystander proliferation. J Exp Med 2001; 194: 1187-1194.

27. Burkett PR, Koka R, Chien M, Chai S, Boone DL, Ma A. Coordinate expression and trans presentation of interleukin (IL)-15Ralpha and IL-15 supports natural killer cell and memory CD8 + T cell homeostasis. J Exp Med 2004; 200: 825-834.

28. Hildeman D, Jorgensen T, Kappler J, Marrack P. Apoptosis and the homeostatic control of immune responses. Curr Opin Immunol 2007; 19: 516-521.

29. Zong WX, Lindsten T, Ross AJ, MacGregor GR, Thompson CB. BH3-only proteins that bind pro-survival $\mathrm{Bcl}-2$ family members fail to induce apoptosis in the absence of $\mathrm{Bax}$ and Bak. Genes Dev 2001; 15: 1481-1486.

30. Hildeman DA, Zhu Y, Mitchell TC, Bouillet P, Strasser A, Kappler J et al. Activated $T$ cell death in vivo mediated by proapoptotic bcl-2 family member bim. Immunity 2002; 16: 759-767.

31. Stonier SW, Ma LJ, Castillo EF, Schluns KS. Dendritic cells drive memory CD8 T-cell homeostasis via IL-15 transpresentation. Blood 2008; 112: 4546-4554.

32. Yajima T, Yoshihara K, Nakazato K, Kumabe S, Koyasu S, Sad S et al. IL-15 regulates CD8 $+T$ cell contraction during primary infection. J Immunol 2006; 176: 507-515.
33. Kurtulus S, Tripathi P, Moreno-Fernandez ME, Sholl A, Katz JD, Grimes HL et al. Bcl-2 allows effector and memory CD8 $+\mathrm{T}$ cells to tolerate higher expression of Bim. J Immunol 2011; 186: 5729-5737.

34. Tripathi P, Kurtulus S, Wojciechowski S, Sholl A, Hoebe K, Morris SC et al. STAT5 is critical to maintain effector CD8 + T cell responses. J Immunol 2010; 185: 2116-2124.

35. Maclver NJ, Michalek RD, Rathmell JC. Metabolic regulation of T lymphocytes. Annu Rev Immunol 2013; 31: 259-283.

36. Chen L, Willis SN, Wei A, Smith BJ, Fletcher Jl, Hinds MG et al. Differential targeting of prosurvival Bcl-2 proteins by their BH3-only ligands allows complementary apoptotic function. Mol Cell 2005; 17: 393-403.

37. Certo M, Del Gaizo Moore V, Nishino M, Wei G, Korsmeyer S, Armstrong SA et al. Mitochondria primed by death signals determine cellular addiction to antiapoptotic BCL-2 family members. Cancer Cell 2006; 9: 351-365.

38. Zhao Y, Altman BJ, Coloff JL, Herman CE, Jacobs SR, Wieman HL et al. Glycogen synthase kinase 3alpha and 3beta mediate a glucose-sensitive antiapoptotic signaling pathway to stabilize Mcl-1. Mol Cell Biol 2007; 27: 4328-4339.

39. Alves NL, Derks IA, Berk E, Spijker R, van Lier RA, Eldering E. The Noxa/Mcl-1 axis regulates susceptibility to apoptosis under glucose limitation in dividing T cells. Immunity 2006; 24: 703-716.

40. Tripathi $\mathrm{P}$, Koss B, Opferman JT, Hildeman DA. Mcl-1 antagonizes Bax/Bak to promote effector CD4(+) and CD8 + + ) T-cell responses. Cell Death Differ 2013; 20: 998-1007.

41. Sarkar S, Kalia V, Haining WN, Konieczny BT, Subramaniam S, Ahmed R. Functional and genomic profiling of effector CD8 T cell subsets with distinct memory fates. $J$ Exp Med 2008; 205: 625-640.

42. Obar JJ, Jellison ER, Sheridan BS, Blair DA, Pham QM, Zickovich JM et al Pathogen-induced inflammatory environment controls effector and memory CD8 + T cell differentiation. J Immunol 2011; 187: 4967-4978.

43. Kaech SM, Tan JT, Wherry EJ, Konieczny BT, Surh CD, Ahmed R. Selective expression of the interleukin 7 receptor identifies effector CD8 T cells that give rise to long-lived memory cells. Nat Immunol 2003; 4: 1191-1198.

44. Zhang L, Zhang H, Li L, Xiao Y, Rao E, Miao Z et al. TSC1/2 signaling complex is essential for peripheral naive CD8 + T cell survival and homeostasis in mice. PLoS One 2012; 7 e30592.

45. Sullivan JA, Kim EH, Plisch EH, Peng SL, Suresh M. FOXO3 regulates CD8 T cell memory by T cell-intrinsic mechanisms. PLoS Pathog 2012; 8: e1002533.

46. Kerdiles YM, Beisner DR, Tinoco R, Dejean AS, Castrillon DH, DePinho RA et al. Foxo1 links homing and survival of naive T cells by regulating L-selectin, CCR7 and interleukin 7 receptor. Nat Immunol 2009; 10: 176-184.

47. Bardwell PD, Gu J, McCarthy D, Wallace C, Bryant S, Goess C et al. The Bcl-2 family antagonist ABT-737 significantly inhibits multiple animal models of autoimmunity. J Immunol 2009; 182: 7482-7489.

48. Carrington EM, Vikstrom IB, Light A, Sutherland RM, Londrigan SL, Mason KD et al. BH3 mimetics antagonizing restricted prosurvival Bcl-2 proteins represent another class of selective immune modulatory drugs. Proc Natl Acad Sci USA 2010; 107: 10967-10971.

49. Villunger A, Michalak EM, Coultas L, Mullauer F, Bock G, Ausserlechner MJ et al. p53- and drug-induced apoptotic responses mediated by $\mathrm{BH} 3-o n l y$ proteins puma and noxa. Science 2003; 302: 1036-1038. 